Article

\title{
Spatio-Temporal Variability of Aerosol Components, Their Optical and Microphysical Properties over North China during Winter Haze in 2012, as Derived from POLDER/PARASOL Satellite Observations
}

\author{
Yang Ou ${ }^{1,2} \mathbb{D}^{\mathbb{D}}$, Lei $\mathrm{Li}^{3}$, Zhengqiang Li ${ }^{1,2, * \mathbb{D}}$, Ying Zhang ${ }^{1,2} \mathbb{D}$, Oleg Dubovik ${ }^{4} \mathbb{D}$, Yevgeny Derimian ${ }^{4}(\mathbb{D}$, \\ Cheng Chen ${ }^{5} \mathbb{D}$, David Fuertes ${ }^{5}$, Yisong Xie ${ }^{1}$, Anton Lopatin ${ }^{5}$, Fabrice Ducos ${ }^{4}$ and Zongren Peng ${ }^{1}$
}

1 State Environmental Protection Key Laboratory of Satellite Remote Sensing, Aerospace Information Research Institute, Chinese Academy of Sciences, Beijing 100101, China; ouyang2018@radi.ac.cn (Y.O.); zhangying02@radi.ac.cn (Y.Z.); xieys@radi.ac.cn (Y.X.); pengzr@aircas.ac.cn (Z.P.)

2 University of Chinese Academy of Sciences, Beijing 100049, China

3 Key Laboratory of Atmospheric Chemistry, Chinese Academy of Meteorological Sciences, CMA, Beijing 100081, China; lilei@cma.gov.cn

4 LOA-Laboratoire d'Optique Atmosphérique, CNRS, UMR 8518, University of Lille, 59000 Lille, France; oleg.dubovik@univ-lille.fr (O.D.); yevgeny.derimian@univ-lille.fr (Y.D.); fabrice.ducos@univ-lille.fr (F.D.)

check for updates

Citation: Ou, Y.; Li, L.; Li, Z.; Zhang, Y.; Dubovik, O.; Derimian, Y.; Chen, C.; Fuertes, D.; Xie, Y.; Lopatin, A.; et al. Spatio-Temporal Variability of Aerosol Components, Their Optical and Microphysical Properties over North China during Winter Haze in 2012, as Derived from POLDER/PARASOL Satellite Observations. Remote Sens. 2021, 13, 2682. https://doi.org/10.3390/ rs13142682

Academic Editor: Miroslav Kocifaj

Received: 17 May 2021

Accepted: 5 July 2021

Published: 7 July 2021

Corrected: 10 February 2023

Publisher's Note: MDPI stays neutra with regard to jurisdictional claims in published maps and institutional affiliations.

Copyright: (C) 2021 by the authors Licensee MDPI, Basel, Switzerland. This article is an open access article distributed under the terms and conditions of the Creative Commons Attribution (CC BY) license (https:// creativecommons.org/licenses/by/ $4.0 /)$.
GRASP-SAS, Remote Sensing Developments, Cite Scientifique, University of Lille, 59655 Villeneuve d'Ascq, France; cheng.chen@grasp-sas.com (C.C.); david.fuertes@grasp-sas.com (D.F.); anton.lopatin@grasp-sas.com (A.L.)

* Correspondence: lizq@radi.ac.cn

Abstract: Pollution haze is a frequent phenomenon in the North China Plain (NCP) appearing during winter when the aerosol is affected by various pollutant sources and has complex distribution of the aerosol properties, while different aerosol components may have various critical effects on air quality, human health and radiative balance. Therefore, large-scale and accurate aerosol components characterization is urgently and highly desirable but hardly achievable at the regional scale. In this respect, directional and polarimetric remote sensing observations have great potential for providing information about the aerosol components. In this study, a state-of-the-art GRASP/Component approach was employed for attempting to characterize aerosol components in the NCP using POLDER/PARASOL satellite observations. The analysis was done for January 2012 in Beijing (BJ) and Shanxi (SX). The results indicate a peak of the $\mathrm{BC}$ mass concentration in an atmospheric column of $82.8 \mathrm{mg} / \mathrm{m}^{2}$ in the SX region, with a mean of $29.2 \mathrm{mg} / \mathrm{m}^{2}$ that is about four times higher than one in BJ $\left(8.9 \mathrm{mg} / \mathrm{m}^{2}\right)$. The mean BrC mass concentrations are, however, higher in BJ (up to ca. $271 \mathrm{mg} / \mathrm{m}^{2}$ ) than that in SX which can be attributed to a higher anthropogenic emission. The mean amount of fine ammonium sulfate-like particles observed in the BJ region was three times lower than in SX $\left(131 \mathrm{mg} / \mathrm{m}^{2}\right)$. The study also analyzes meteorological and air quality data for characterizing the pollution event in BJ. During the haze episode, the results suggest a rapid increase in the fine mode aerosol volume concentration associated with a decrease of a scale height of aerosol down to $1500 \mathrm{~m}$. As expected, the values of aerosol optical depth (AOD), absorbing aerosol optical depth (AAOD) and fine mode aerosol optical depth $\left(\mathrm{AOD}_{\mathrm{f}}\right)$ are much higher on hazy days. The mass fraction of ammonium sulfatelike aerosol increases from about $13 \%$ to $29 \%$ and mass concentration increases from $300 \mathrm{mg} / \mathrm{m}^{2}$ to $500 \mathrm{mg} / \mathrm{m}^{2}$. The daily mean $\mathrm{PM}_{2.5}$ concentration and $\mathrm{RH}$ independently measured during these reported pollution episodes reach up to $425 \mathrm{~g} / \mathrm{m}^{3}$ and $80 \%$ correspondingly. The monthly mean mass concentrations of other aerosol components in the BJ are found to be in agreement with the results of previous research works. Finally, a preliminary comparison of these remote sensing derived results with literature and in situ $\mathrm{PM}_{2.5}$ measurements is also presented.

Keywords: aerosol components; aerosol optical properties; aerosol microphysical properties; remote sensing; POLDER 


\section{Introduction}

In recent years, haze pollution has drawn growing worldwide concerns, especially in developing countries. Haze pollution is frequently observed during winter in North China Plain (NCP) because of both the enhanced emissions from heating, traffic and industry and the unfavorable meteorological conditions for diffusion [1]. An increasing number of studies focused on haze events associated with significant impacts on air quality, human health and global climate change [2-4]. It is well known that secondary inorganic aerosols, such as $\mathrm{SO}_{4}^{2-}, \mathrm{NO}^{3-}{ }^{-}, \mathrm{NH}_{4}{ }^{4+}$ and organic aerosol $(\mathrm{OA})$ are the dominant air pollutants in hazes $[5,6]$. The primary aerosol or precursor can react to form a secondary aerosol which is the main component of $\mathrm{PM}_{2.5}$ under certain environmental conditions [7]. Therefore, the research on aerosol components is the key to revealing the forming mechanism of haze [2].

Currently, most of the existing studies focused on aerosol components are based on the chemical sampling method [2,5,7-9]. For instance, Cao et al. [8] collected the atmospheric organic and elemental carbon (OC and EC) during the high-pollution fall and winter in Xi'an city, Shaanxi Province, from September 2003 to February 2004 using Battery-powered mini-volume samplers to collect $\mathrm{PM}_{2.5}$ and PM10 samples. Their study reported that the average EC content of $\mathrm{PM}_{2.5}$ in Xi'an in the winter of 2003 was $(12.3 \pm 3) \mu \mathrm{g} / \mathrm{m}^{3}$ and OC and EC levels at $\mathrm{Xi}^{\prime}$ an are higher than most urban cities in Asia. Sun et al. [7] conducted synchronous aerosol particle measurements with two aerosol mass spectrometers in Beijing to investigate the variations in particulate composition. Their study indicated that secondary organic aerosol is the dominant pollutant and that reducing the precursors of secondary aerosol over regional scales is crucial and effective in suppressing the formation of secondary particulates and in mitigating PM pollution.

In-depth analysis of chemical components of aerosol from remote sensing data is very challenging and practically impossible. At the same time, many studies in recent years have demonstrated significant potential in providing information about aerosol composition by identifying and characterizing main aerosol components (types) using ground-based remote sensing observations [10-17]. For instance, Li et al. [11,18] applied the five-aerosol-component model (relying on the differences of the complex refractive indices (CRI) of different components) for analyzing the ground-based observations during the heavy haze pollution events in Beijing in January 2013. Similarly, Li et al. [12] investigated the microphysical, optical, and chemical properties of atmospheric aerosols using the CRI acquired in Beijing and Kanpur sites of AERONET (Aerosol Robotic NETwork). Furthermore, Zhang et al. [17] proposed an algorithm that can distinguish the organic matter components (water-soluble organic matter and water-insoluble organic matter) from other aerosol components during the haze in Beijing. Nevertheless, the studies mentioned above use ground-based observations and therefore face a common limitation in spatial coverage of aerosol components distribution.

In these regards, satellite remote sensing provides an opportunity to provide aerosol observations. However, there have only been a few successful attempts to use satellite remote sensing for characterizing the component distribution of aerosol. In these regards, multi-angular polarimetric (MAP) data seem to have sufficient information content for detailed characterization of aerosol [19]. For example, the algorithms of new generation can derive information about not only total aerosol optical depth (AOD) at $550 \mathrm{~nm}$ characterizing total aerosol amount but also AOD spectral dependence of, and even information about such detailed properties as spectral absorption aerosol optical depth (AAOD), complex refractive index and particle nonsphericity [20,21]. As discussed by Russell et al. [22], the possibilities of retrieving these extended aerosol properties (CRI and volume particles size distribution, etc.) from satellite polarimetry could be raised once new prospects of monitoring of aerosol components from space are realized. Chen et al. [23,24] used aerosol AOD and AAOD products retrieved from POLDER-3/PARASOL polarimetric data for constraining global emissions of aerosols. Moreover, Li et al. [18] developed in the frame of GRASP algorithm $[21,25]$ an approach designed for direct retrieval of main aerosol components from directional polarimetric satellite observations. The successful 
applicability of this approach was illustrated in several studies [26,27]. In this study, we explore the utilization of this approach in conjunction with analysis of the air quality and meteorological data.

Specifically, we derive accurate spatial distribution of aerosol optical, microphysical properties and aerosol components from POLDER/PARASOL satellite observations over NCP. We also focus on the pollution haze events that occurred over Beijing in January 2012. We analyzed the simultaneously derived aerosol components, aerosol optical depth (AOD), particle size distribution, scale height and the observed meteorological and $\mathrm{PM}_{2.5}$ data in Beijing during the haze events. A comparison with non-haze cases was also performed. The data and methods of this study are described in Sections 2 and 3. We show the spatial distribution of aerosol properties and the relationship between the aerosol components and meteorological data in Section 4. The analysis and discussion are presented in Section 5. Section 6 presents the conclusions.

\section{Data and Study Area}

\subsection{POLDER/PARASOL Satellite Observations}

The spaceborne multi-directional, multi-spectral polarized POLDER-3 (Polarization and Directionality of the Earth's Reflectance) imager on board PARASOL (Polarization and Anisotropy of Reflectance for Atmospheric Sciences coupled with Observations from a Lidar) can measure the global angular distribution of intensity and polarization of solar radiation reflected into space by the earth-atmosphere system [28-30]. In January 2012, the revisit observation period of the POLDER satellite over the NCP was two days. PARASOL was in a sun-synchronous orbit with ascending node at 13:30 [31], with two-day revisiting period. The imager's channels are centered at 443, 490, 565, 670, 763, 765, 865, 910 and $1020 \mathrm{~nm}$ and polarization observations are at 490,670 and $865 \mathrm{~nm}$. The spatial resolution at nadir is $5.3 \mathrm{~km} \times 6.2 \mathrm{~km}$. POLDER-3 can observe up to 16 view angles for each pixel. The POLDER-3 mission was accomplished in 2013 and it has provided about nine years of valuable data, which can be downloaded from http:/ / www.icare.univ-lille1.fr/archive? dir=PARASOL/ (accessed on 25 May 2020). The full archive of the POLDER-3 data was processed by GRASP algorithms and several extended aerosol products were generated [19]. The extended validation and analysis of Chen et al. [32] demonstrated several advantages of MAP $10 \mathrm{~km}$ products compared to the conventional products provided by single viewing images. Schutgens et al. [33] analyzed the consistency and difference of different satellite aerosol degree products and demonstrated the reliability and unique value of MAP aerosol products especially in regard to such property as aerosol absorption.

In this study, GRASP aerosol component retrieval methodology is used to retrieve information about aerosol components on North China Plain from POLDER-3 multi-angle and multi-spectral polarized observations [18]. As shown in Figure 1, over this region, on average about 10 times a month POLDER-3 data were available after the cloud screening. We average all available pixels for BJ and SX in January 2012, respectively. However, it should be noted that the number of observations in BJ and SX regions in a month is not the same, which may have a slight impact on the comparison of aerosol component.

\subsection{The Validation Ground-Based Data}

The ground-based data used in this study for validation include aerosol optical depth (AOD), absorbing aerosol optical depth (AAOD) and fine aerosol optical depth $\left(\mathrm{AOD}_{\mathrm{f}}\right)$ from three AERONET stations (Beijing (BJ), Xianghe $(\mathrm{XH})$ and Xinglong $(\mathrm{XL})$ ) during January 2012. AERONET is a ground observation network comprised of a group of groundbased remote-sensing aerosol sites established by NASA to detect the global atmospheric aerosol (http:/ /aeronet.gsfc.nasa.gov (accessed on 25 December 2020)) [34]. The direct Sun AOD and extended retrieved aerosol properties of level 1.5 data cloud screened and level 2.0 passed additional quality control, including quality checks, stability criterion check and standard deviation check were used for validation purposes [35,36]. If there were no level 2.0 data available, the level 1.5 data were used. The uncertainty of AOD in the visible and 
near-infrared bands is $\sim 0.01$ [37]. The direct Sun AOD observations are conducted every 15 min according to the AERONET operational protocol. The angular sky radiance scanning, which is collected less frequently ( once per hour) and only at low sun elevation angles, is used to derive aerosol microphysical and absorption characteristics, including AAOD [35]. Thus, the number of derived AOD substantially exceeds that of AAOD.

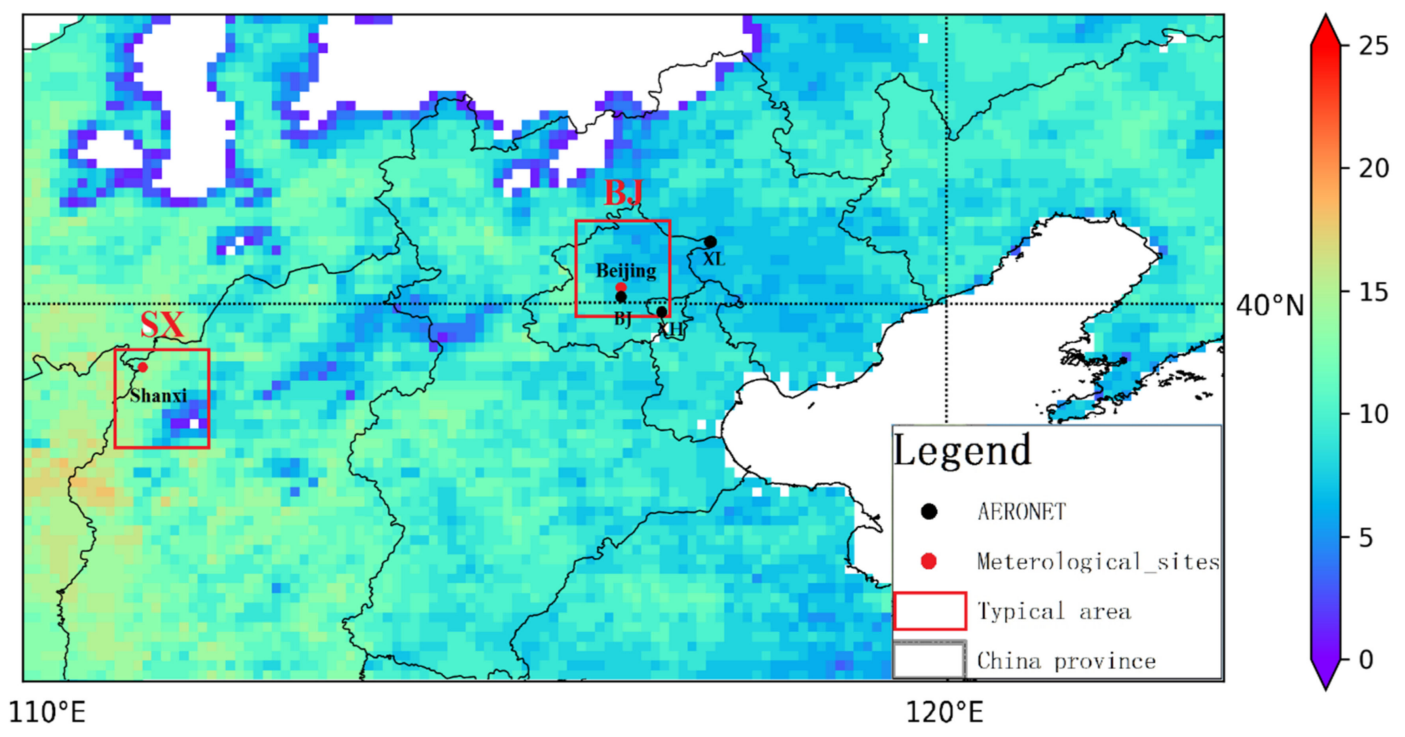

Figure 1. Number of pixels in $0.1^{\circ} \times 0.1^{\circ}$ resolution observed by POLDER/PARASOL satellite over the North China Plain in January 2012. (Black points represent the AERONET sites (Beijing, Xianghe and Xinglong); red points represent the meteorological stations (Beijing and Shanxi); red square frames show the two selected regions BJ and SX, respectively.)

In addition to AERONET data, the ambient relative humidity $(\mathrm{RH})$, temperature, wind direction and wind speed, which were collected by the automatic meteorological stations (NO.54398 Beijing $\left(40.08^{\circ} \mathrm{N} 116.37^{\circ} \mathrm{E}\right)$ ) of the China Meteorological Administration (CMA) were used in order to analyze the ground surface observations. Only data from manned stations, which are maintained regularly, were used to ensure the possible data quality. The CMA stations close to the three AERONET sites mentioned in the last paragraph were selected. The temporal windows of observation are the same as AERONET. The hourly atmospheric fine particulate matter $\left(\mathrm{PM}_{2.5}\right.$ aerodynamic diameter less than $\left.2.5 \mathrm{~m}\right)$ mass concentrations observed over the US Embassy of Beijing to identify pollution events were also used (https:/ / china.usembassy-china.org.cn/ (accessed on 16 June 2010)) [38].

\subsection{Study Area}

NCP is a densely populated region in China and is polluted due to high emissions of pollutants and precursors associated with the economic development [39]. The spatial distribution of aerosol components in NCP is in the lack of further research. NCP shows the typical characteristics of a temperate continental climate with four distinctive seasons. In this region, there are many diversified and fast-developing cities, such as Beijing which has a dense population and serious atmospheric pollution. The vast number of atmospheric pollutants primarily originates from major pollution sources, such as air discharged from vehicles and coal-burning [40-44].

In this study, we have chosen the square regions BJ and SX with $1^{\circ} \times 1^{\circ}$ in Beijing and Shanxi, as shown in Figure 1, to ensure the existence of valid data. Beijing is the capital of China with a high population density [45]. Shanxi is a province with a rich storage of coal resources in China [8,46]. These two regions present different environmental characteristics and anthropogenic activities. Therefore, BJ and SX are chosen as typical cases to discuss the difference of aerosol optical properties, microphysical properties and aerosol components' spatial distributions in NCP. The central longitude and latitude of the $\mathrm{BJ}$ and $\mathrm{SX}$ are $116.5^{\circ} \mathrm{E}$, $40^{\circ} \mathrm{N}$ and $108.5^{\circ} \mathrm{E}, 36.5^{\circ} \mathrm{N}$, respectively. 


\section{Methods}

\subsection{GRASP/Component Retrieval}

GRASP (Generalized Retrieval of Aerosol and Surface Properties) is a highly rigorous and versatile aerosol and surface reflectance retrieval algorithm which is available at (https:/ / www.grasp-open.com (accessed on 1 July 2020)) [21,25]. The algorithm can equally be applied (with minimal changes) to inverting observations from different satellite sensors and ground-based instruments [47-50]. A full description of the main "Forward Model" and "Numerical Retrieval" algorithm modules is provided by Dubovik et al. [51]. The schematic flowchart of the GRASP retrieval algorithm is shown in Figure 2. The aerosol properties in the forward model of GRASP rely on a spheroid kernel data base for the calculation of single scattering properties [50]. The multiple scattering effects are accounted for using the successive order of scattering (SOS) radiative transfer approach [52]. The inversion is designed as statistically fitting using the multi-term least square method (LSM) [53].

Recently a module for aerosol component retrieval was incorporated into the GRASP algorithm, called the GRASP/Components algorithm, in order to directly infer information about aerosol components from measured radiances together with size distribution that allows for retrieving also all optical properties such as aerosol optical depth in fine and coarse mode, single scattering albedo, etc. [26,27]. The main specifics of GRASP/Components relate to the modeling of aerosol optical properties. As shown in Figure 2 the aerosol is modeled as an internal mixture of several aerosol components with known spectral dependencies of the CRI of the aerosol components that are fixed a priori. Correspondingly, the aerosol optical properties are driven by size distribution and CRI that is computed using Maxwell-Garnett mixing rules from the volume fractions of the components. As shown in Figure 2, the volume fractions of the components are included in the state vector of retrieved unknowns. Maxwell-Garnett effective medium approximation should be used for the case of insoluble impurities suspended in solution, which can be modeled as insoluble inclusions embedded within a matrix [54]. Thus, the algorithm derives the volume fractions of these components that drive spectral dependence of the complex refractive index, which are used together with size distribution to calculate the mass column concentrations of each aerosol component and total aerosols.

Figure 2 illustrates the main logic of the GRASP/Components algorithm iterative solution. The forward model module simulates satellite observation and measurement based on state vector that includes parameters describing the particles size distribution, aerosol vertical profile, fractions of aerosol components and surface reflectance as the following. The CRI of all aerosol components are known parameters from previous research [55]. The CRI is calculated by the aerosol internal mixing model, by assuming that the aerosol particles are regular particles (such as spherical or ellipsoidal) or nonspherical. Once the real and imaginary parts of aerosol complex refractive indices are computed based on the fractions of aerosol components, the aerosol single scattering properties are calculated using the spheroid kernel data base by Dubovik et al., (2006). Then the radiative transfer module accounts for multiple scattering interactions of light scattered by particles of aerosol, molecules of gases and reflected by the surface to generate the observations. In this study, all the radiances in six wavelengths and polarized radiances in three wavelengths of POLDER-3 are used for calculation. These calculations are used in iterative numerical inversion realized as statistically optimized fitting. Then the optimal solution of the cost function of algorithm are the retrieval results. For each individual pixel, GRASP uses multiple a priori constraints such as smoothness limitations on the retrieved continuous functions including aerosol size distribution and surface parameters. Thus, it could bring additional possibilities for improving the accuracy of retrieved parameters. The details of the approach are provided by Dubovik et al., (2011) and Li et al., (2019). Once the iterations stop and the solution is found, output aerosol properties are calculated that include additional characteristics such as $\mathrm{AOD}_{\mathrm{f}}, \mathrm{AODc}, \mathrm{AAOD}$, etc. 


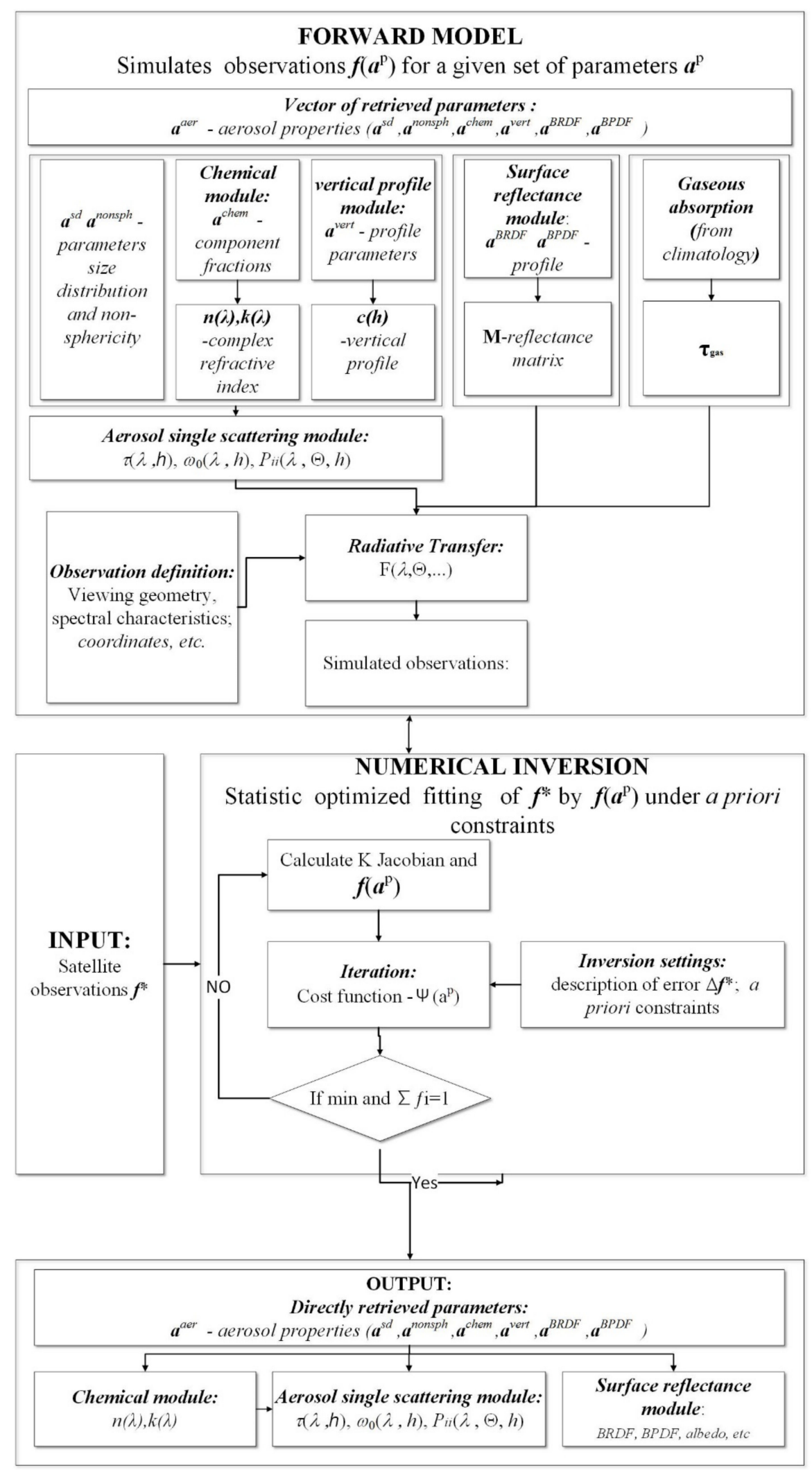

Figure 2. Flowchart of the main retrieval steps in GRASP algorithm. ( $\boldsymbol{a}^{\text {chem }}$-fractions of components; $\boldsymbol{a}^{\text {sd }}$ _size distribution parameters; $\boldsymbol{a}^{\text {nonsph }}$ _fraction of nonsperical particles; $\boldsymbol{a}^{\text {vert }}$ - parameters of vert. profile; $a^{B R D F}$ - parameters of BRDF; $a^{B P D F}$ - parameters of BPDF). 


\subsection{Aerosol Mass to Volume Conversion}

As discussed by Li et al. [18], the aerosol components provided by the GRASP/Component approach of are BC (black carbon); BrC (brown carbon); CAI (coarse-mode absorbing insoluble); CNAI (coarse-mode non-absorbing insoluble); FNAI (fine-mode non-absorbing insoluble); FNAS (fine-mode non-absorbing soluble); CNAS (coarse-mode non-absorbing soluble); AWF (aerosol water of fine-mode); AWC (aerosol water of coarse-mode) (Table 1).

Table 1. Abbreviations of aerosol components and optical and microphysical parameters.

\begin{tabular}{ccc}
\hline Abbreviations & Component & Densities \\
\hline BC & black carbon & $\mathrm{BC}=2.0 \mathrm{~g} / \mathrm{cm}^{3}$ \\
BrC & brown carbon & $\mathrm{BrC}=1.8 \mathrm{~g} / \mathrm{cm}^{3}$ \\
CAI & coarse-mode absorbing insoluble & $\mathrm{CAI}=4.77 \mathrm{~g} / \mathrm{cm}^{3}$ \\
CNAI & coarse-mode non-absorbing insoluble & $\mathrm{CNAI}=2.6 \mathrm{~g} / \mathrm{cm}^{3}$ \\
FNAI & fine-mode non-absorbing insoluble & $\mathrm{FNAI}=2.6 \mathrm{~g} / \mathrm{cm}^{3}$ \\
FNAS & fine-mode non-absorbing soluble & $\mathrm{FNAS}=1.76 \mathrm{~g} / \mathrm{cm}^{3}$ \\
CNAS & coarse-mode non-absorbing insoluble & $\mathrm{CNAS}=2.24 \mathrm{~g} / \mathrm{cm}^{3}$ \\
AWF & aerosol water of fine-mode & $\mathrm{FAWC}=1.0 \mathrm{~g} / \mathrm{cm}^{3}$ \\
AWC & aerosol water of coarse-mode & $\mathrm{CAWC}=1.0 \mathrm{~g} / \mathrm{cm}^{3}$ \\
$\mathrm{AOD}$ & aerosol optical depth & \\
$\mathrm{AOD}$ & fine aerosol optical depth & \\
$\mathrm{AAOD}$ & absorbing aerosol optical depth & \\
$\mathrm{CRI}$ & complex refractive indices & \\
$\mathrm{n}_{\mathrm{f}}$ & real part of CRI for fine mode & \\
$\mathrm{n}_{\mathrm{c}}$ & real part of CRI for coarse mode & \\
$\mathrm{k}_{\mathrm{f}}$ & imaginary part of CRI for fine mode & \\
$\mathrm{k}_{\mathrm{c}}$ & imaginary part of CRI for coarse mode & \\
$\mathrm{FMFV}_{\mathrm{f}}$ & fine-mode fraction by volume & \\
\hline
\end{tabular}

In order to calculate the mass concentration of these aerosol components, the densities of various aerosol components are found in previous literature $\left(\mathrm{BC}=2.0 \mathrm{~g} / \mathrm{cm}^{3}, \mathrm{BrC}=1.8 \mathrm{~g} / \mathrm{cm}^{3}\right.$, FNAI and $\mathrm{CNAI}=2.6 \mathrm{~g} / \mathrm{cm}^{3}, \mathrm{CAI}=4.77 \mathrm{~g} / \mathrm{cm}^{3},{ }_{\mathrm{FNAS}}=1.76 \mathrm{~g} / \mathrm{cm}^{3}, \mathrm{CNAS}=2.24 \mathrm{~g} / \mathrm{cm}^{3}, \mathrm{AWF}$ and $\left.{ }_{\mathrm{AWC}}=1.0 \mathrm{~g} / \mathrm{cm}^{3}\right)[15,56]$. With these parameters, the aerosol mass concentration over NCP for January 2012 can be calculated by the following formula:

$$
C_{m, i}=\rho_{m, i} \cdot f_{i} \cdot V_{\text {total }}=\rho_{m, i} \cdot f_{i} \cdot \int_{r_{\min }}^{r_{\max }} \frac{d V}{d \ln r} d \ln r
$$

where $C_{m, i}$ is the column mass concentration of the $i$-th component, which is the mass concentration of the aerosol component in the total atmosphere per unit area (unit: $\mathrm{mg} / \mathrm{m}^{2}$ ), $\rho_{m, i}$ is the mass density of the $i$-th component [15], $\rho_{m, i}$ is the total aerosol volume, $f_{i}$ is the volume fraction of the $i$-th component. $r_{\max }$ and $r_{\min }$ represent the maximum and minimum radius of aerosol volume size distribution, respectively.

\section{Results}

\subsection{GRASP/Component Retrieval}

Thus, GRASP/Component approach was applied to processing POLDER-3 data over the selected studied regions. Figure 3 demonstrates the spatial inhomogeneities and the spectral behavior of different aerosol characteristics including AOD, AAOD and $\mathrm{AOD}_{\mathrm{f}}$ in different time periods. It should be noted that considering optical characteristics such as $\mathrm{AOD}_{\mathrm{f}}$ and $\mathrm{AAOD}$ is for the air pollution characterization. Figure 3 shows the spatial distribution of monthly AOD over NCP during January 2012. The high AOD and $\mathrm{AOD}_{\mathrm{f}}$ were observed in the Hebei and eastern Shandong provinces. The results suggest that the fine mode is the main part of the aerosol. It is also consistent with the results obtained by Li et al. [26]. The AAOD of Hebei and Shandong province are also higher than those in the Shanxi $\left(110^{\circ} 15^{\prime} \mathrm{E}-114^{\circ} 32^{\prime} \mathrm{E} ; 34^{\circ} 36^{\prime} \mathrm{N}-40^{\circ} 44^{\prime} \mathrm{N}\right)$, especially at 670,865 and $1020 \mathrm{~nm}$. Moreover, the spectral behavior of AOD in the 440-1020 nm range manifests itself in 
monotonic decrease as the wavelength increases, which is consistent with the results obtained by Chen et al. [32]. A similar spectral dependency was observed for $\mathrm{AOD}_{\mathrm{f}}$ and AAOD. This tendency is typically expected for fine-mode dominated aerosols [57]. Thus, in most of the analyzed areas the fine mode aerosol is a principal contributor to the extinction of radiation and the largest spatial inhomogeneities of $\mathrm{AOD}_{\mathrm{f}}$ are caused by aerosol particle size distribution.
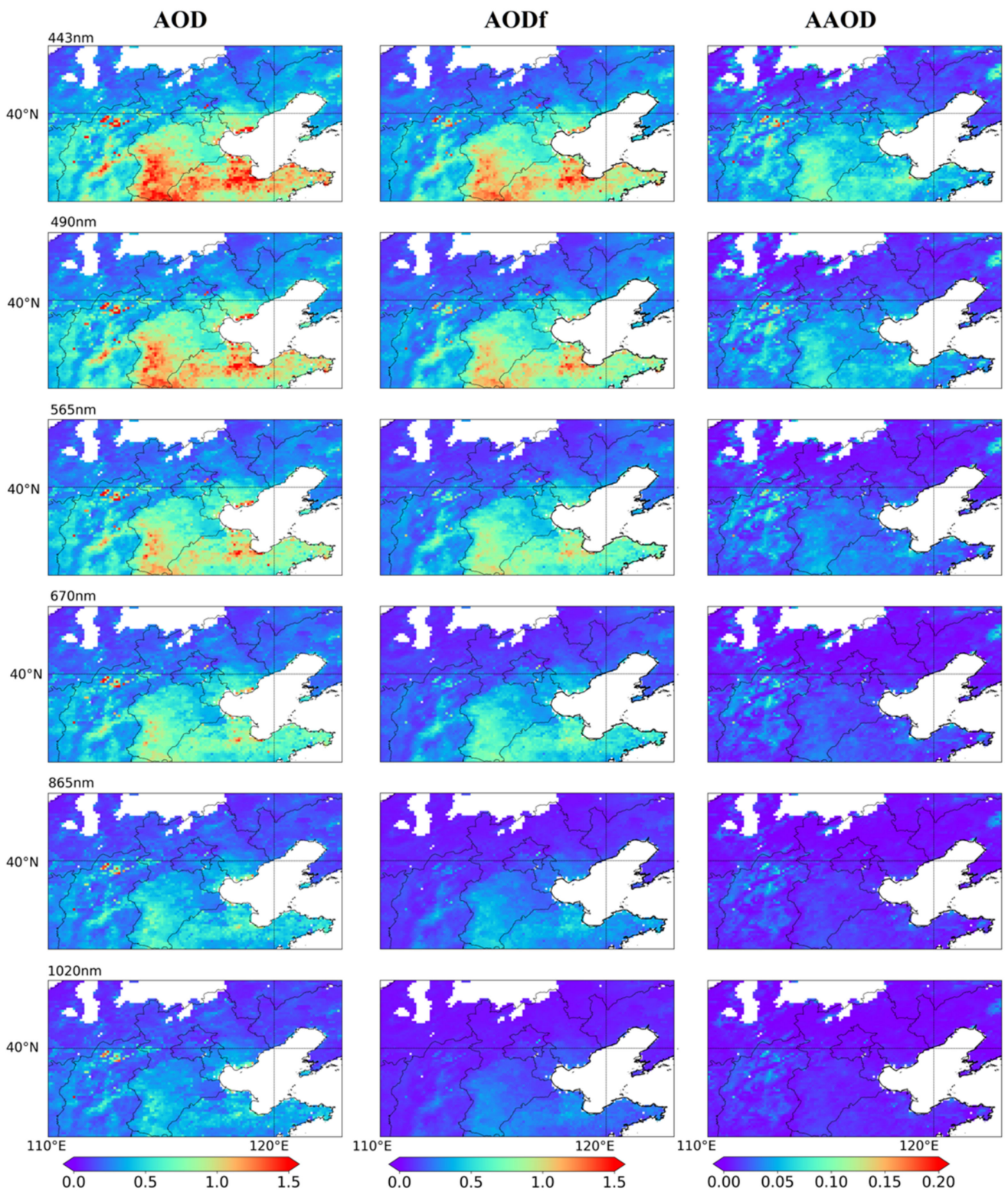

Figure 3. Monthly mean AOD, $\mathrm{AOD}_{\mathrm{f}}$, AAOD at 443, 490, 565, 670, 865, $1020 \mathrm{~nm}$ in January 2012 as retrieved from POLDER-3/PARASOL satellite observations.

\subsection{Spatial Distribution of Volume Size Distribution Properties}

The aerosol size distribution is commonly approximated by log-normal distribution as discussed by [58-61]. The retrieved aerosol volume size distributions are usually considered bi-modal composed by fine and coarse mode of aerosol particles. Correspondingly, the fine-mode fraction by volume (FMFv) is often used for analyzing the main features of spatial variability aerosol sizes. The FMFv can be defined as [62]: 


$$
F M F v=\frac{C_{v f}}{C_{v f}+C_{v c}}=\frac{\int_{r_{f \min }}^{r_{f \max }} \frac{d V(\ln r)}{d \ln r} d \ln r}{\int_{r_{\text {fmin }}}^{r_{f \max }} \frac{d V(\ln r)}{d \ln r} d \ln r+\int_{r_{c \min }}^{r_{c \max }} \frac{d V(\ln r)}{d \ln r} d \ln r}
$$

where $C_{v f}$ and $C_{v c}$ denote the volume concentration of fine and coarse mode aerosol; rf and $r_{c}$ are the radii of fine and coarse mode; the subscripts min and max denote the minimum and maximum radius of each mode, respectively and $d V(\ln r) / d \ln r$ denotes the volume size distribution. The FMFv of the north of Hebei and Shandong province is obviously higher than in other regions approximately by value 0.2 as shown in Figure 4 . This spatial distribution feature is similar to $\mathrm{AOD}_{\mathrm{f}}$. It indicates that the fine mode aerosol represents the main part of the aerosol concentration related to the pollutant's accumulation. At the same time, some high values of FMFv are also observed over the Inner Mongolia of north China where AOD is not high. In addition, the reliability of FMFv in the low aerosol conditions is low. The uncertainty of FMFv is larger when the AOD is lower than 0.05. The FMFv could be used as a reference.

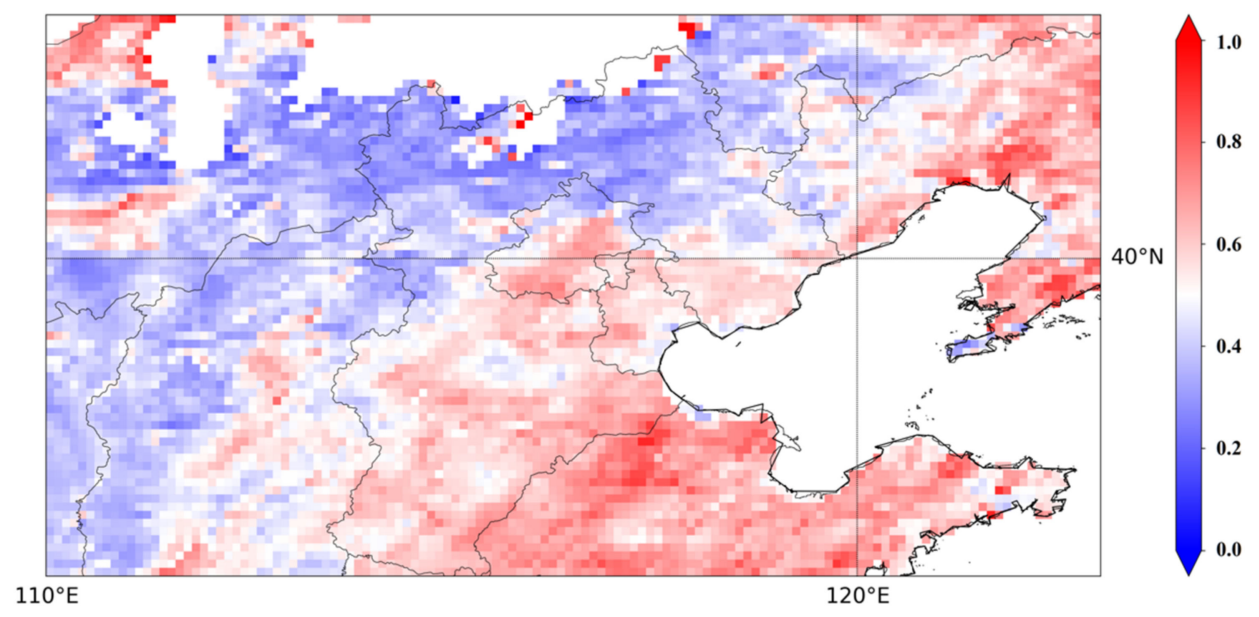

Figure 4. Monthly mean fine-mode fraction by volume in January 2012 as retrieved from POLDER3/PARASOL satellite observations.

\subsection{Spatial Distribution of Complex Refractive Index}

The complex refractive index (CRI) of aerosol defines the ability of material composing aerosol particles to scatter and absorb the radiation. The distribution of CRI over NCP in January 2012 is shown in Figure 5. Based on the retrieval result for the imaginary and real part of CRI for fine and coarse modes $\left(\mathrm{k}_{\mathrm{f}}, \mathrm{k}_{\mathrm{c}}\right.$ and $\mathrm{n}_{\mathrm{f}}, \mathrm{n}_{\mathrm{c}}$, respectively), the distinctive regional features can be identified in the aerosol characteristics over NCP. The high $\mathrm{k}_{\mathrm{f}}$ values mainly occurred in Shanxi province. The monthly $\mathrm{k}_{\mathrm{c}}$ have higher values mainly in Hebei region in a difference from the values of $\mathrm{k}_{\mathrm{f}}$. On the contrary, the spatial distribution characteristics of monthly $\mathrm{n}_{\mathrm{c}}$ are basically uniform with slight fluctuation.

The $\mathrm{n}_{\mathrm{c}}$ and $\mathrm{n}_{\mathrm{f}}$ of NCP exhibit relatively similar spectral behaviors in 440-1020 nm, with its monthly mean varying between 1.45 and 1.55 with the monthly mean at six wavelengths. Particularly, compared to the real parts, the imaginary parts $\mathrm{k}_{\mathrm{c}}$ show obvious spectral variation, with the values in the $443 \mathrm{~nm}$ and $490 \mathrm{~nm}$ values being significantly higher than that of other bands, which is in accordance with Li et al. [11]. 

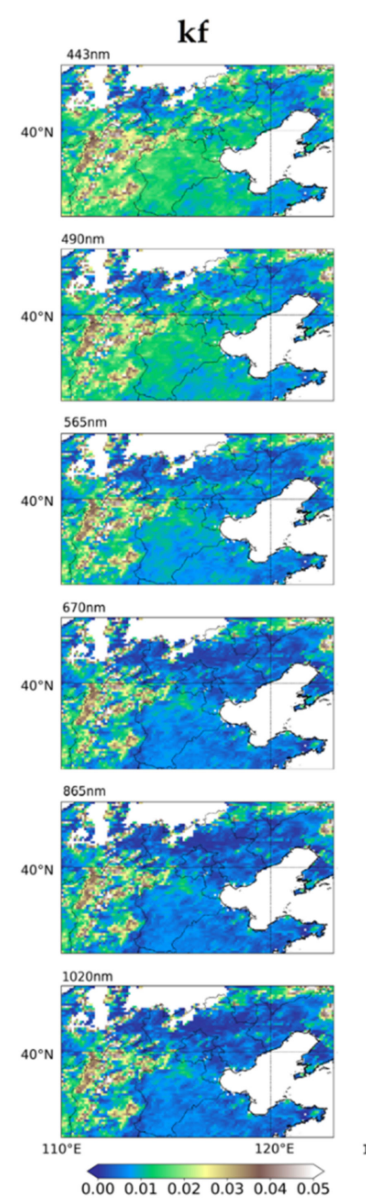

kc
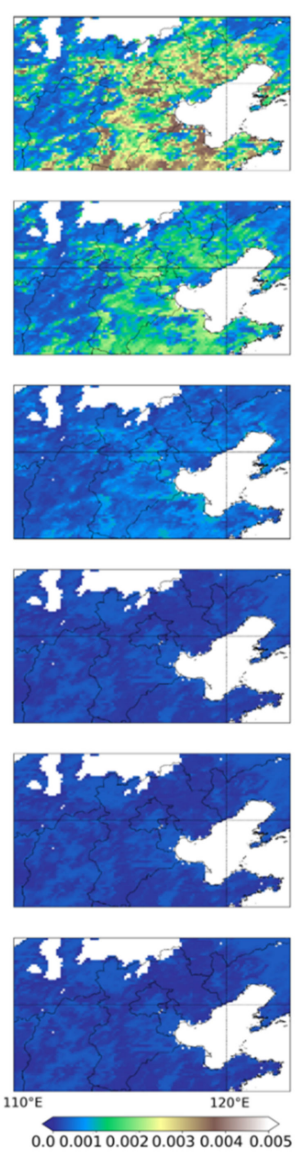

nf
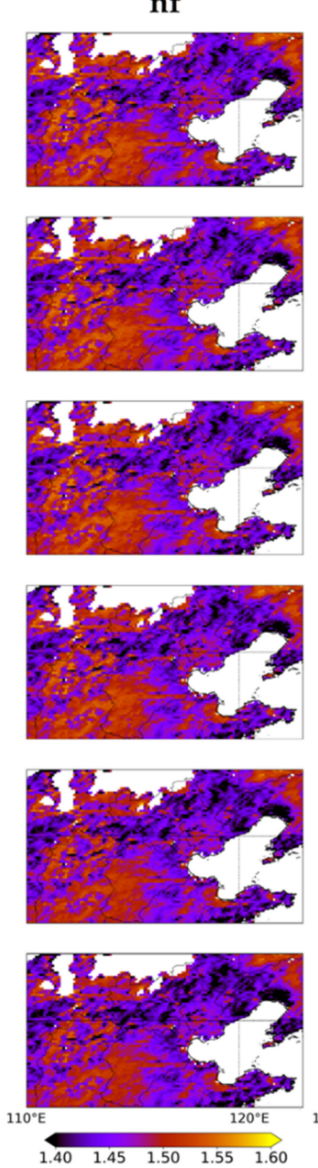

nc
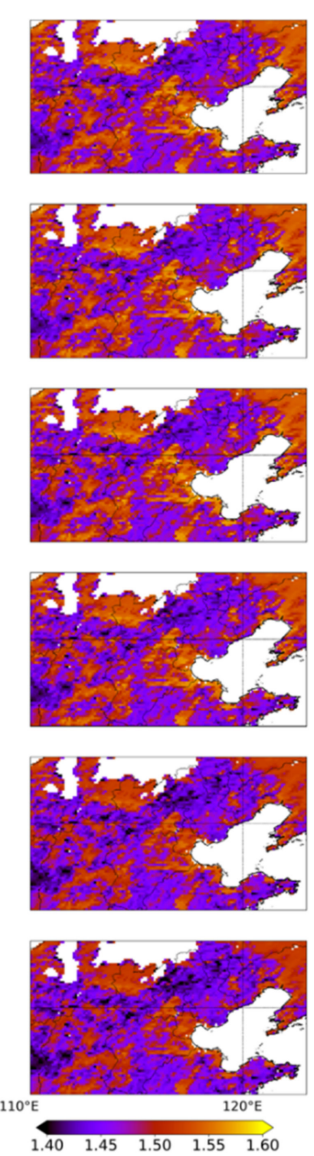

Figure 5. Monthly imaginary refractive index of fine mode $\left(\mathrm{k}_{\mathrm{f}}\right)$ and coarse mode $\left(\mathrm{k}_{\mathrm{c}}\right)$, real refractive index of fine mode $\left(n_{f}\right)$ and coarse mode $\left(n_{c}\right)$ at 443, 490, 565, 670, 865, $1020 \mathrm{~nm}$ in January 2012 as retrieved from POLDER-3/PARASOL satellite observations.

\subsection{Spatial Distribution of Aerosol Components}

The retrieved monthly mean of total aerosol column mass concentration is about $2000 \mathrm{mg} / \mathrm{m}^{2}$ based on the POLDER-3 observation data in January 2012. Figure 6 shows the spatial distribution of black carbon, and it can be seen from the figure that the mass concentration of BC is mainly centered in northwestern Shanxi. It is about four times higher compared to Beijing $\left(8.9 \mathrm{mg} / \mathrm{m}^{2}\right)$ as shown in Table 1 . In addition, it is worth noting that the high values of $\mathrm{BrC}$ are mainly stored in Beijing, Tianjin, southern Hebei and northern Shandong. The high mass concentration of $\operatorname{BrC}\left(127.4 \mathrm{mg} / \mathrm{m}^{2}\right)$ possibly indicates that the primary air pollution sources are the fine particles produced by anthropogenic activities in Beijing. Moreover, the FNAS mainly spatially distributed in coastal regions such as Bohai Bay in Figure 6. The mean FNAS $\left(381.2 \mathrm{mg} / \mathrm{m}^{2}\right)$ in Beijing is three times higher compared with Shanxi $\left(130.1 \mathrm{mg} / \mathrm{m}^{2}\right)$. In these regions, the high relative humidity is favorable to the growth of ammonium sulfate aerosol particles. The high mass concentration of FNAS $\left(381.2 \mathrm{mg} / \mathrm{m}^{2}\right)$ implies that the vehicle and industrial emissions are the dominant factors, for the inorganic salts of emissions are the major components of the FNAS. However, the spatial distributions of monthly mean CNAI, FNAI, CAI, AWF and AWC are uniform with slight fluctuation over NCP as shown in Figure 6. The peak of BC mass concentration in January 2012 is $82.8 \mathrm{mg} / \mathrm{m}^{2}$ in Shanxi of NCP. The mean BrC mass concentrations with the maximum at $271.2 \mathrm{mg} / \mathrm{m}^{2}$ in Hebei and Beijing are higher than those in Shanxi because of the enormous anthropogenic emissions. The FNAS is centralized in the Bohai Bay due to the high relative humidity, with its mass concentration around $737.4 \mathrm{mg} / \mathrm{m}^{2}$. In addition, the high values of CNAS are shown in Figure 6, due to coarse mode soluble carbonaceous particles shown in previous retrievals $[15,18]$. At the same time, OC (organic carbon) is 
the fine mode non-absorbing insoluble component, which has a significant presence in the aerosol during the haze $[63,64]$. In this study, the OC are mixed in the FNAI, which is the possible reason for the high value concentrated in the southern of NCP in the spatial distribution of FNAI.
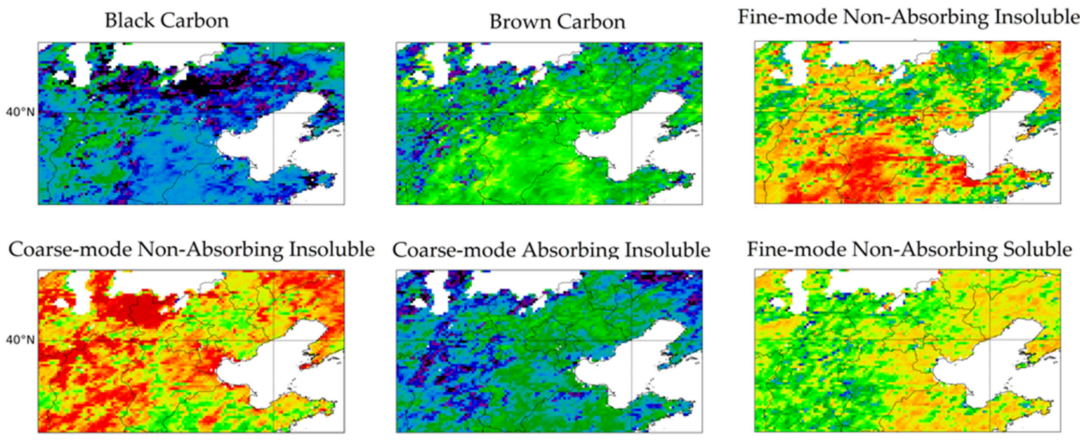

Coarse-mode Non-Absorbing Soluble

Aerosol Water of Fine-mode
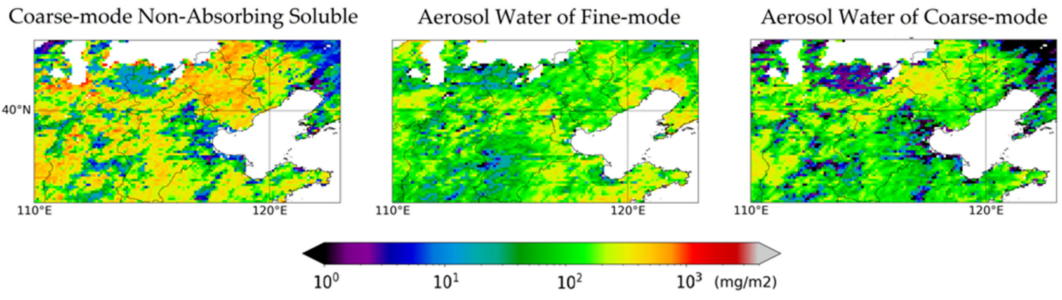

$10^{1}$

$10^{2}$

$10^{3}(\mathrm{mg} / \mathrm{m} 2)$

Figure 6. Monthly mean aerosol components mass concentrations $\left(\mathrm{mg} / \mathrm{m}^{2}\right)$ in January 2012 retrieved from POLDER-3/PARASOL satellite observations.

\section{Validation and Intercomparison}

\subsection{Validation of Aerosol Optical Properties}

Figure 7 shows the validation of $A O D, A_{f}$ and AAOD results with AERONET measurements. For the temporal window, we used a time interval of $\pm 1 \mathrm{~h}$ of satellite overpass time. The spatial window is a $3 \times 3$ pixels centered on the AERONET site for validating the $\mathrm{AOD}, \mathrm{AOD}_{\mathrm{f}}$ and $\mathrm{AAOD}$ [65]. The accuracies of these properties are evaluated using the Pearson correlation coefficient (R), Root Mean Square Error (RMSE) and expected error (EE). Good fraction (Gfrac), the percentage of scatter points that fall in $\mathrm{EE}$, is often used to evaluate the quality of inversion.
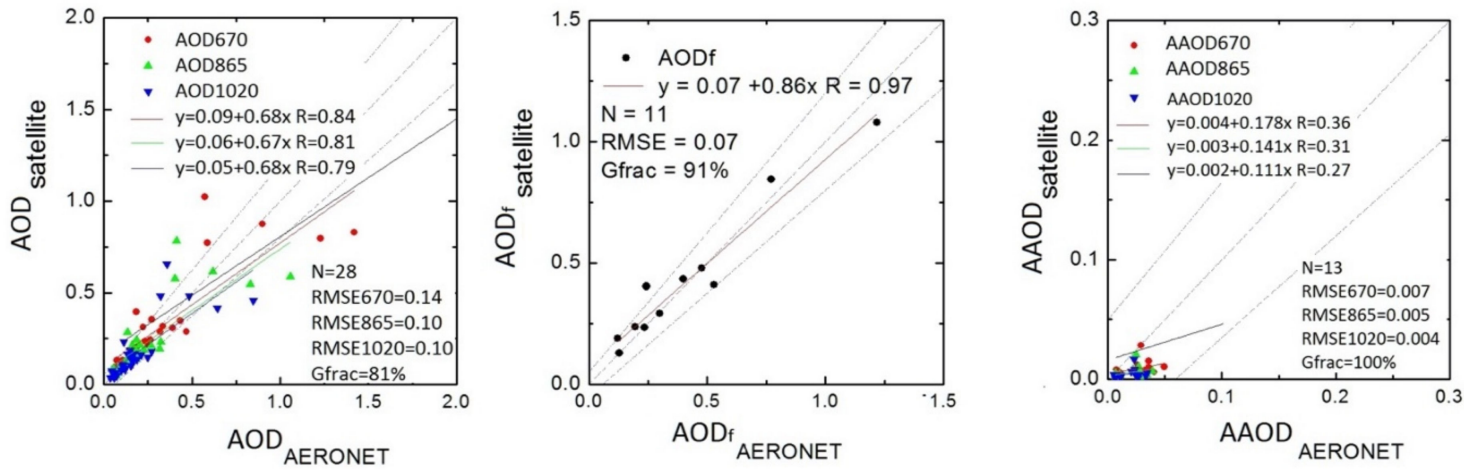

Figure 7. The comparison of aerosol optical properties AOD retrieved in this study from POLDER-3/PARASOL and AOD provided by AERONET for three AERONET sites located in North China Plain during the period January 2012. Red points represent the $670 \mathrm{~nm}$, green points represent the $865 \mathrm{~nm}$ and blue points represent the $1020 \mathrm{~nm}$. N is the total number of results. The dotted lines are the expected error lines $(\mathrm{EE}= \pm(0.05+15 \%))$.

The AOD validation results show the correlation coefficient $(\mathrm{R})$ at $670 \mathrm{~nm}$ is 0.84 , which is the best, the R of $865 \mathrm{~nm}(0.81)$ inferior to that at $670 \mathrm{~nm}$, and R of $1020 \mathrm{~nm}$ is the lowest (0.79). The RMSE of AOD is 0.13 and the Gfrac of $81 \%$. The $\mathrm{AOD}_{\mathrm{f}}$ is compared with the ground-based AERONET data available only at 500nm. Therefore, we utilized $\mathrm{AOD}_{\mathrm{f}}$ at 
$490 \mathrm{~nm}$ to validate with $\mathrm{AOD}_{\mathrm{f}}$ at $500 \mathrm{~nm}$ [66]. The validation of $\mathrm{AOD}_{\mathrm{f}}$ showed a high $\mathrm{R}$ of 0.97 and a low RMSE of 0.07 , the Gfrac of $91 \%$, respectively. However, the R of AAOD is the highest (0.36) at $670 \mathrm{~nm}$ among all bands, and the R of $865 \mathrm{~nm}$ is only 0.31 . Thus, the correlation coefficient $(R)$ of AAOD is significantly lower than for the AOD and $A O D_{f}$. This is expected since retrieval aerosol absorption is challenging from satellites especially when AOD is low [32].

\subsection{Complex Refractive Index}

CRI of fine and coarse modes may differ significantly due to different components and source. In our study, the observed spectral behavior of the $\mathrm{k}_{\mathrm{f}}, \mathrm{k}_{\mathrm{c}}$ and $\mathrm{n}_{\mathrm{f}}, \mathrm{n}_{\mathrm{c}}$ values are consistent with the results obtained by Zhang et al. [17]. As shown in Figure 8, we find the mean $n_{f}$ and $n_{c}(1.46$ and 1.50) in January 2012 calculated by Zhang et al. [17] based on ground-based data are close to the values $\left(n_{f}=1.45\right.$ and $\left.n_{c}=1.50\right)$ retrieved by satellite observations in this study. The difference in $n_{f}$ is 0.1 , but the values of $n_{c}$ are the same. Moreover, the $\mathrm{k}_{\mathrm{f}}$ and $\mathrm{k}_{\mathrm{c}}$ of Zhang et al. [17] can be presented using four distinct values $\mathrm{k}_{\mathrm{f}}$ $440, \mathrm{k}_{\mathrm{f}}$ and $\mathrm{k}_{\mathrm{c}} 440, \mathrm{k}_{\mathrm{c}}\left(0.036,0.021,0.0018\right.$ and 0.0009 , respectively). The mean $\mathrm{k}_{\mathrm{f}}$ and $\mathrm{k}_{\mathrm{c}}$ of all bands in this study are 0.008 and 0.0015 , respectively. On the whole, the values of $k_{f}$ in this study are generally lower than Zhang et al. [17], the $n_{f}, n_{c}$ and $k_{c}$ show great agreement with Zhang et al. [17]. In addition, the SD of $k_{c}$ given by Zhang et al., 2020 is larger, which means that the aerosol absorption has changed a lot during the observation period. The SD is relatively small in this study, which may be related to the spectral smoothing constraint on the CRI of the GRASP inversion algorithm.
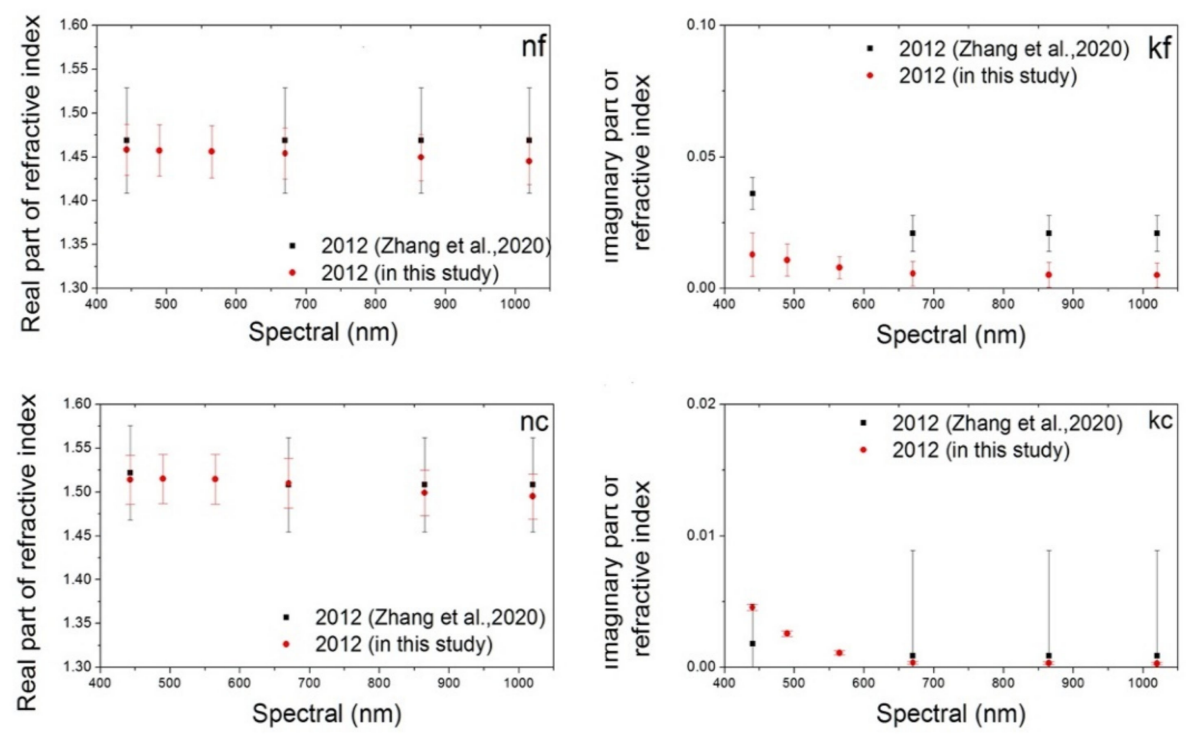

Figure 8. Comparison complex refractive index derived by Zhang et al. [17] for January 2012 in Beijing and the values retrieved in present study from POLDER-3/PARASOL satellite observations. Adapted with permission from ref. [17], Copyright 2020 Atmospheric Chemistry and Physics.

\subsection{Intercomparison of Aerosol Component Distribution}

In order to compare the aerosol component characterization using results given by the GRASP/Component approach with the ones of ground-based, a reformulation components approximation using a six-aerosol-component model is suggested $[11,16,18,56]$. This representation includes black carbon $(\mathrm{BC})$, brown carbon $(\mathrm{BrC})$, dust-like (DU), fine ammonium sulfate-like (ASF), coarse ammonium sulfate-like (ASC) and aerosol water content (AW). To this end, we sum up the CAI, CNAI and FNAI as the DU. The sum of the FAWC and CAWC was defined as AW. The FNAS is renamed as ASF and the CNAS is renamed as the ASC in this study.

Thus, in this study, we mainly discussed the spatial distribution of aerosol component presence under different air quality conditions and their relationship with meteorological 
conditions, especially haze. We used the six-aerosol-component model including the following components black carbon $(B C)$, brown carbon $(B r C)$, dust-like (DU), fine ammonium sulfate-like (ASF), coarse ammonium sulfate-like (ASC) and aerosol water content (AW). Black carbon (BC) is universally known as soot carbon and the strongest light-absorbing carbon found in the atmosphere $[67,68]$. Brown carbon $(\mathrm{BrC})$ relates with organic matter that contains some absorbing organic species and generally has much greater absorptivity at near-ultraviolet and blue wavelengths than at red wavelengths [69]. Dust-like (DU) particles are regarded as a substance with strong absorption at the UV and blue wavelengths. DU particles usually come from natural sources, when iron oxides are present, but they can also be generated by the anthropogenic aerosol particles and mixed with some organic carbon (OC) [70]. The ammonium sulfate-like (ASF) are mainly generated from the secondary photochemical reaction by such as vehicle exhaust and oxygen [71]. Coarse ammonium sulfate-like (ASC) component mainly composed of ammonium sulfate-like and few sodium chlorides has the most significant contribution to light scattering [72]. ASC is dominated by coarse aerosol particles coming from natural sources and it has similar light scattering properties as the ASF component. Water content (AW) is primarily a host, which is related to hygroscopic components ASF and ASC, as well as ambient RH, especially at high-humidity situations [16].

Figure 9 shows the comparison of aerosol component mass fractions and mass concentration obtained in this study with the values reported in the literature for January 2012 in Beijing $[11,16,18,56]$. Their difference shown in Figure 9 can be partly explained by the fact that the other studies do not consider sea salt. In general, the concentration of BC is the lowest among aerosol components, the mass concentration is less than $10 \mathrm{mg} / \mathrm{m}^{2}$, and the mass fraction is less than $1 \%$. The mass concentration and mass fraction of $\mathrm{BrC}$ are higher than that of $\mathrm{BC}$. The mass concentration of $\mathrm{BrC}$ is about $100 \mathrm{mg} / \mathrm{m}^{2}$ in Beijing during the same period, which is in accordance with the results of Wang et al. [56]. Additionally, the DU is the dominant aerosol component with concentration higher than those of ASF and AW in all studies, about $50 \%$. Moreover, the mass concentration and mass fraction of ASF and AW are similar. Thus, these results show that the proportions of various aerosol components are in line with the conclusions drawn by previous studies.

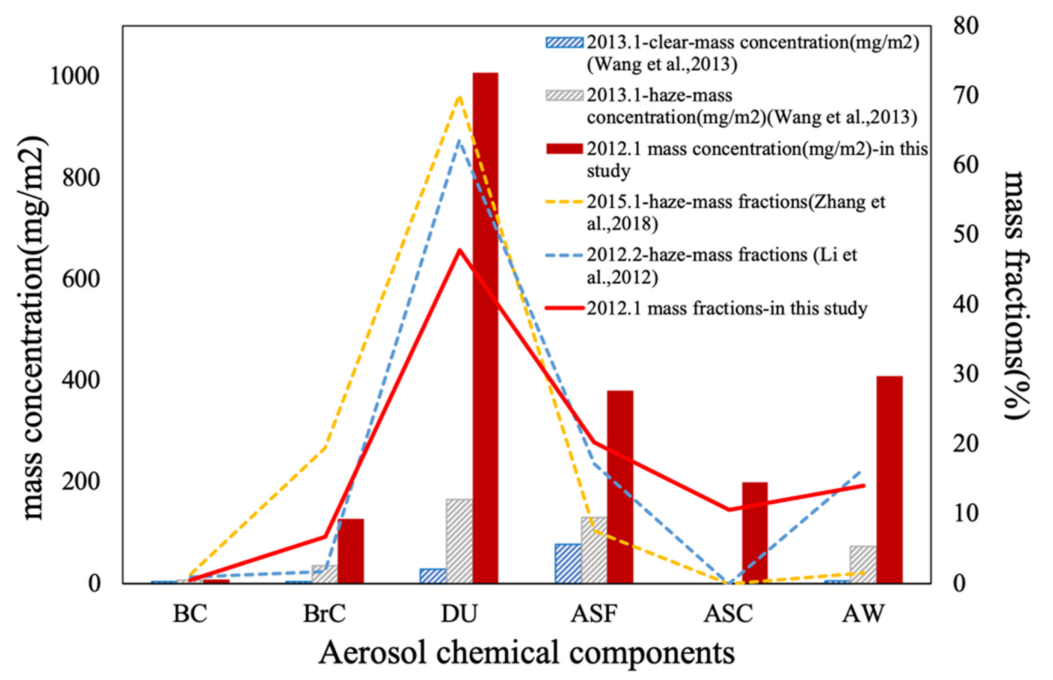

Figure 9. Comparison of aerosol component values reported in the literature and results of the present study for January 2012 in Beijing. The red line represents the mass fractions in this study, the yellow dash line represents the haze mass fractions of Zhang et al. [16], the blue dash line represents the haze mass fractions of Li et al. [11]. The red bar represents the mass concentration in this study, the gray bar represents the haze mass concentration of Wang et al. [56], the blue bar represents the clear mass concentration of Wang et al. [56]. Adapted with permission from ref. [11,16,56], Copyright 2013 Atmospheric Chemistry and Physics; 2018 Atmospheric Environment; 2013 Journal of Geophysical Research. 


\section{Discussion}

\subsection{Aerosol Properties in Typical Regions}

Table 2 shows the monthly mean values of aerosol optical, microphysical and compositional properties in typical regions (BJ and SX in Figure 1) derived for comparing the differences in their spatial distributions. The highest value of AOD has occurred in BJ region, up to 1.1. The mean $\mathrm{AOD}$ of $\mathrm{BJ}$ is also the highest. The apparently highest value of $\mathrm{AOD}_{\mathrm{f}}$ of up to 0.9 is also observed in $\mathrm{BJ}$. The lowest $\mathrm{AOD}_{\mathrm{f}}$ value of 0.21 was observed in SX region. The difference between the mean $\mathrm{AOD}_{\mathrm{f}}$ in $\mathrm{BJ}$ and $\mathrm{SX}$ is about 0.37 . In contrast, the spatial difference of AAOD is small, and the mean values in the two cases are similar (mean values 0.012 and 0.010 , respectively) as shown in Table 1 . Moreover, the highest value of FMFv was observed at 0.8 in BJ region. The high imaginary part $(\mathrm{k})$ of the fine mode values mainly occurred in SX region (maximum is 0.046 ) indicating the strong absorption of fine-mode particles in this region, due to high black carbon mass concentration up to $29.2 \mathrm{mg} / \mathrm{m}^{2}$. Meanwhile, the substation level of mass concentration of BC was mainly observed in SX $\left(29 \mathrm{mg} / \mathrm{m}^{2}\right)$, which is in good agreement with Li et al. [11]. The peak of $\mathrm{BrC}$ is $271 \mathrm{mg} / \mathrm{m}^{2}$ in BJ, due to the complex organic pollutant. However, the spatial distributions of monthly mean DU, SS and AW are uniform, and their concentrations are $1008 \mathrm{mg} / \mathrm{m}^{2}$, $200 \mathrm{mg} / \mathrm{m}^{2}, 410 \mathrm{mg} / \mathrm{m}^{2}$ in BJ region and $1608 \mathrm{mg} / \mathrm{m}^{2}, 167 \mathrm{mg} / \mathrm{m}^{2}, 230 \mathrm{mg} / \mathrm{m}^{2}$ in SX region, respectively.

Table 2. Monthly mean aerosol optical microphysical properties and components of BJ and SX case study (BJ and SX regions in Figure 1). Max is the maximum, $\min$ is the minimum, SD is the standard error deviation.

\begin{tabular}{|c|c|c|c|c|c|c|c|c|}
\hline & \multicolumn{3}{|c|}{ BJ } & \multicolumn{5}{|c|}{ SX } \\
\hline & $\operatorname{Max}$ & Mean & Min & SD & Max & Mean & Min & SD \\
\hline $\mathrm{AOD}(670 \mathrm{~nm})$ & 1.09 & 0.96 & 0.41 & 1.56 & 0.94 & 0.91 & 0.46 & 0.77 \\
\hline $\mathrm{AOD}_{\mathrm{f}}(670 \mathrm{~nm})$ & 0.94 & 0.82 & 0.32 & 1.41 & 0.50 & 0.45 & 0.21 & 0.43 \\
\hline AAOD $(670 \mathrm{~nm})$ & 0.01 & 0.01 & 0.01 & 0.01 & 0.01 & 0.01 & 0.00 & 0.01 \\
\hline $\mathrm{k}_{\mathrm{f}}(670 \mathrm{~nm})$ & 0.014 & 0.006 & 0.002 & 0.00 & 0.046 & 0.022 & 0.004 & 0.02 \\
\hline $\mathrm{k}_{\mathrm{c}}(670 \mathrm{~nm})$ & 0.001 & 0.000 & 0.000 & 0.00 & 0.000 & 0.000 & 0.000 & 0.00 \\
\hline $\mathrm{n}_{\mathrm{f}}(670 \mathrm{~nm})$ & 1.52 & 1.45 & 1.40 & 0.03 & 1.56 & 1.50 & 1.40 & 0.02 \\
\hline $\mathrm{n}_{\mathrm{c}}(670 \mathrm{~nm})$ & 1.56 & 1.51 & 1.43 & 0.03 & 1.54 & 1.50 & 1.41 & 0.00 \\
\hline $\mathrm{FMF}_{\mathrm{V}}$ & 0.79 & 0.78 & 0.60 & 0.08 & 0.64 & 0.62 & 0.38 & 0.20 \\
\hline Scale height (m) & 4316 & 4157 & 3057 & 1168 & 4791 & 4464 & 2710 & 980 \\
\hline $\mathrm{BC}\left(\mathrm{mg} / \mathrm{m}^{2}\right)$ & 25 & 9 & 2 & 2 & 83 & 29 & 3 & 24 \\
\hline $\operatorname{BrC}\left(\mathrm{mg} / \mathrm{m}^{2}\right)$ & 271 & 127 & 34 & 53 & 113 & 33 & 3 & 18 \\
\hline $\mathrm{DU}\left(\mathrm{mg} / \mathrm{m}^{2}\right)$ & 3277 & 1008 & 175 & 233 & 3423 & 1608 & 399 & 299 \\
\hline $\operatorname{ASF}\left(\mathrm{mg} / \mathrm{m}^{2}\right)$ & 737 & 381 & 53 & 128 & 410 & 130 & 11 & 53 \\
\hline $\operatorname{ASC}\left(\mathrm{mg} / \mathrm{m}^{2}\right)$ & 664 & 200 & 30 & 129 & 761 & 167 & 6 & 126 \\
\hline $\mathrm{AW}\left(\mathrm{mg} / \mathrm{m}^{2}\right)$ & 966 & 410 & 65 & 83 & 858 & 230 & 7 & 64 \\
\hline
\end{tabular}

Figure 10 shows the percentage in the mean monthly column mass concentrations for six aerosol components presenting in two regions with the known high level of pollution (BJ and SX). It can be seen that the DU is the dominating component in both regions in January 2012 accounting for $47.84 \%$ and $59.34 \%$ respectively. BC fraction is only around $1 \%$ in both regions. The BC in SX $(1.31 \%)$ is three times higher than that in $\mathrm{BJ}(0.47 \%)$, with a difference of $0.88 \%$. The $\mathrm{BrC}$ aerosol component fraction is at the level of $6.77 \%$ at the BJ regions, which possibly reflects high level of emissions caused by industrial and anthropogenic activities. An obvious difference can be noted between the contribution of $\mathrm{BrC}$ of BJ and SX regions that reaches 5.18\%. Meanwhile, the AW and ASC contributed at the levels of $14 \%$ and $10 \%$ to the aerosol components. Whereas the ASC observed in SX likely can be attributed to coarse mode soluble non-absorbing organic carbon. Another possible reason for the high value of DU is OC amounts are mixed in the DU. That could explain that a higher fraction of aerosol components DU (including OC) are found in SX than BJ due to the burning of biomass such as agricultural straw. The higher percentage of 
BrC component in BJ than SX can probably be explained by the higher presence of fossil fuels combustion products in BJ than in SX.

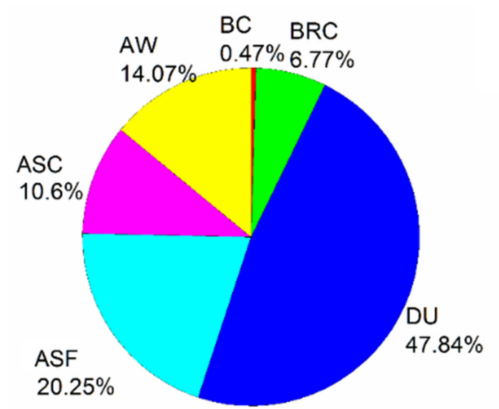

(A)

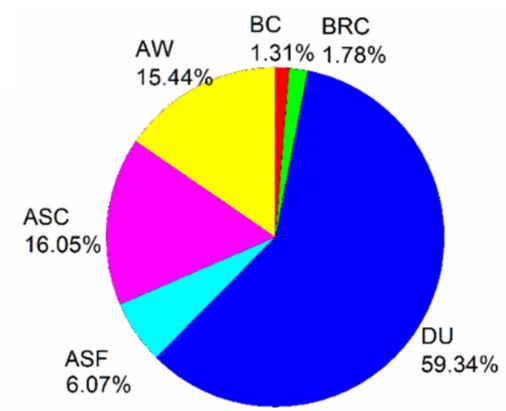

(B)

Figure 10. Monthly mean mass fractions of aerosol components for typical regions in January 2012 as retrieved from POLDER/PARASOL satellite observations in BJ (A) and SX (B) region (as Figure 1).

\subsection{Temporal Variations of Aerosol Properties in Beijing Region}

This section discusses aerosol components results for the BJ region shown in Figure 1, which is a part of Beijing. Based on the results presented above, we analyzed the evolution of the aerosol size distribution and aerosol component combination during January 2012. For a comprehensive analysis we utilized meteorological data of $\mathrm{PM}_{2.5}$ data in Beijing. The daily distribution of the available ground-based meteorological and $\mathrm{PM}_{2.5}$ data is shown in Figure 11. For comparison of aerosol component values retrieved from satellites, we have chosen the closest measurements within $10 \mathrm{~min}$ before and after satellite overpass time. It is worth noting that there was a high air pollution event according to $\mathrm{PM}_{2.5}$ on 15-18 January 2012. According to the China's Environmental Policy, it is a serious pollution (haze case) when the concentration of $\mathrm{PM}_{2.5}$ is greater than $100 \mathrm{~m}$. The standard of $\mathrm{PM}_{2.5}$ light pollution is $100 \mathrm{~m} \sim 150 \mathrm{~m}$, and the standard of heavy pollution is $200 \mathrm{~m} \sim 300 \mathrm{~m}$. Nonhaze case is when the $\mathrm{PM}_{2.5}$ concentration is less than $100 \mathrm{~m}$. When the weather condition is calm or the average wind speed is less than or equal to $3.0 \mathrm{~m}$ for $4 \mathrm{~s}$, dust and sand are floating in the air, making the horizontal visibility less than $10 \mathrm{~km}$. Figure 11 shows the statistics of the relative humidity $(\mathrm{RH})$, temperature, wind speed and wind direction observations at the Beijing site. The highest RH occurs on the 17-18 January 2012, and the lowest value occurs on the 20-24th. During this haze period, the relative humidity and the temperature are higher and the wind speed is lower than non-haze days.

Figure 11 also shows the evolution of aerosol volume particle size distribution, scale height and AOD in the Beijing region in January. It can be seen that there is an obvious process of fine particle generation during the 15-18th marked with yellow and gray bands in the figure, and the fine mode can rapidly increase during haze pollution events, reaching the maximum value of $0.2 \mu \mathrm{m}^{3} / \mu \mathrm{m}^{2}$. Meanwhile, the scale height of aerosol decreases from $2100 \mathrm{~m}$ to $1500 \mathrm{~m}$. The values of $\mathrm{AOD}, \mathrm{AAOD}$ and $\mathrm{AOD}_{\mathrm{f}}$ also show an apparent increasing trend with the maximum value of AOD reaching 1.09 in Beijing. It can also be noted that the mass fraction of ASF aerosol increases from $12.67 \%$ to $28.62 \%$ and the mass concentration of ASF aerosol increases from $300 \mathrm{mg} / \mathrm{m}^{2}$ to $500 \mathrm{mg} / \mathrm{m}^{2}$ which could be partly explained by the increase in water uptake during the haze event and also likely by an accumulation of particle matters due to static and stagnant atmospheric conditions, corresponding to daily $\mathrm{PM}_{2.5}$ concentration up to $425 \mathrm{~g} / \mathrm{m}^{3}$ and $\mathrm{RH}$ up to $80 \%$. Meanwhile, the increase of $\mathrm{RH}$, which is also associated with the high AW mass concentration, seemed to contribute significantly to haze evolution (Figure 12). It is illustrated that meteorological condition has a very important influence on the variation of aerosol components. The higher the relative humidity, the more pronounced the formation of the secondary aerosols [17]. 


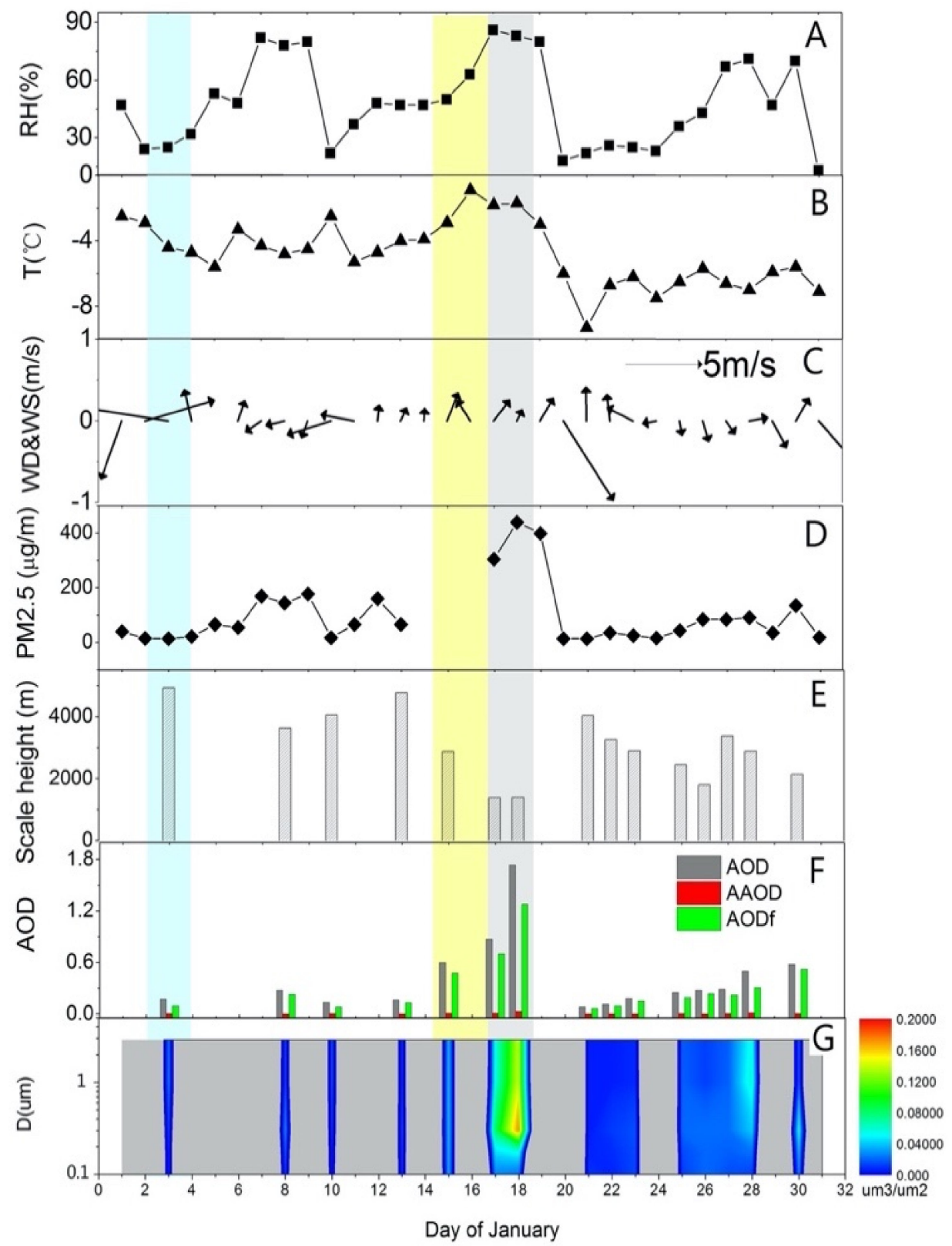

Figure 11. Evolution of meteorological parameters, $\mathrm{PM}_{2.5}$ and results of aerosol retrievals during January 2012. Time series of (A) relative humidity and (B) temperature, $(\mathbf{C})$ wind speed and wind direction (D) $\mathrm{PM}_{2.5}$ (E) scale height and (F) AOD, $\mathrm{AOD}_{\mathrm{f}}, \mathrm{AAOD},(\mathrm{G})$ aerosol volume size distribution.

In order to investigate the evolution of aerosol component mixture during the haze pollution, we have chosen the non-haze case (on 3 January 2012) and dusty case (on 15 January 2012) and haze case (on 17 January 2012) have been chosen to analyze the relationship between different air quality situation and the presence of different aerosol components shown in Figure 12. The dates of analyzed satellite observations are the same as in Figure 11. It is clear that satellite observation data are not available every day. One can see that the DU component is dominant in all aerosol events with the mean percentage of $60 \%$ on $15-16$ January 2012 , which agrees with the weather conditions usually associated with the high presence of dust. The results show a slight increase in $\mathrm{BrC}$ and AS during haze cases compare to non-haze case. However, the concentration of $\mathrm{BrC}$ and ASF demonstrate an obvious increase during the haze case (17-18 January 2012) accounting for $8.83 \%$ and $28.62 \%$, respectively. 
The results showed that the mass concentration of $\mathrm{BrC}$ can be two times greater and the mass concentration of ASF can be five times higher on haze day than on non-haze days. Corresponding daily $\mathrm{PM}_{2.5}$ concentration reached up to $425 \mathrm{~g} / \mathrm{m}^{3}$ and $\mathrm{RH}$ up to $80 \%$. In particular, the amplitude of ASF values in variation between the maximum during the haze cases and the minimum during the non-haze case reaches $400 \mathrm{mg} / \mathrm{m}^{2}$. Similarly, the amplitude of $\mathrm{RH}$ variations reaches $\sim 50 \%$ in the same period. Thus, the increase of ASF in fine mode seems to be mainly influenced by RH. In addition, Figure 11C,D shows a rapid drop of $\mathrm{PM}_{2.5}$ caused by strong northwest wind on 19 January. As can be seen in Figure 12, DU increases from $\sim 1000 \mathrm{mg} / \mathrm{m}^{2}$ to $\sim 1200 \mathrm{mg} / \mathrm{m}^{2}$ from 18 to 21 in January. Meanwhile, evidently a rapid decrease in ASF and $\mathrm{BrC}$ seems to be associated with the penetration of clean air mass in the area.

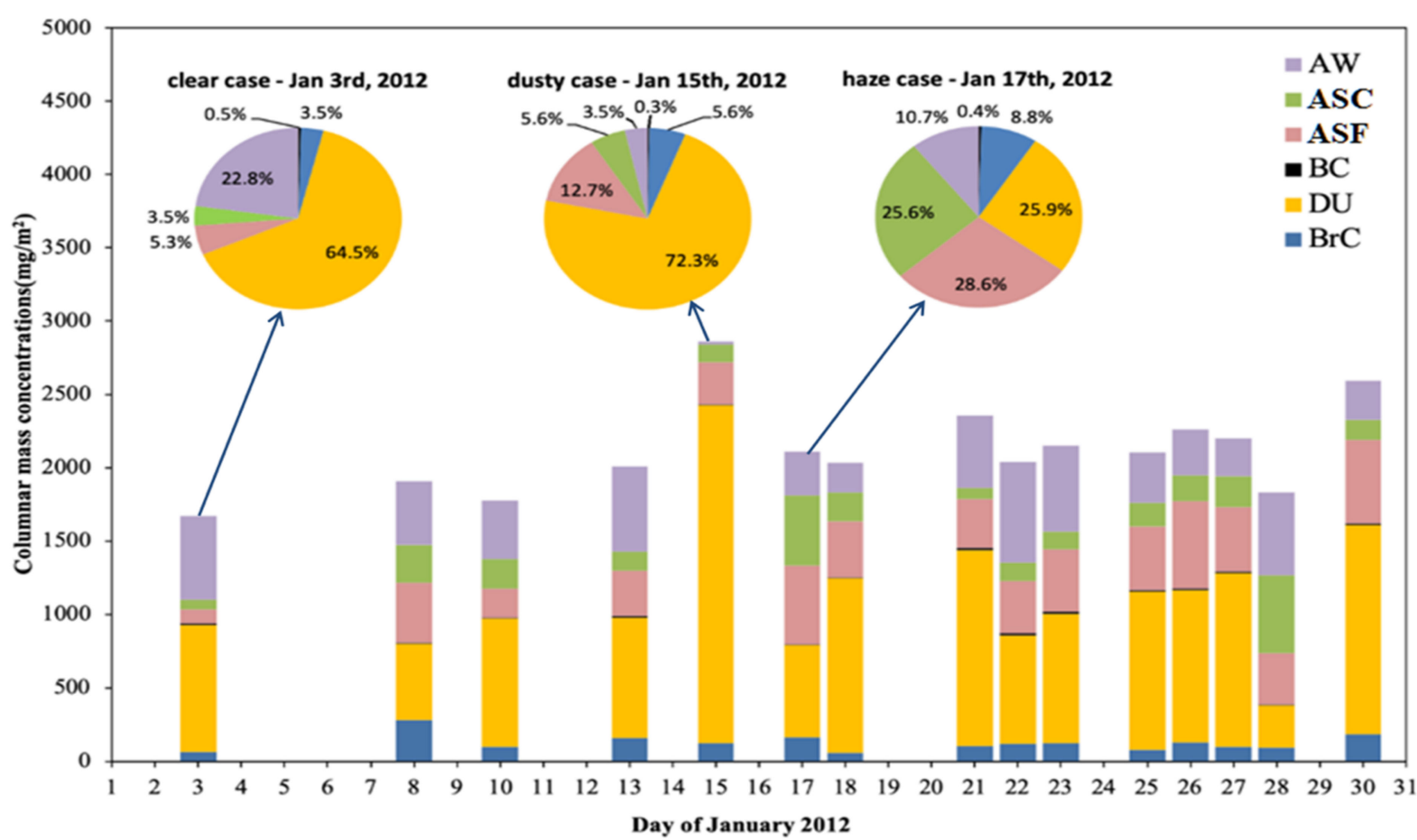

Figure 12. Time series of the daily mean of observed aerosol component mixtures, including BC, BrC, DU, ASF, SS, AW in Beijing region. The pie charts present the average aerosol component mixings for three episodes (clear, dusty and hazy) as marked in the figure.

The results of the study suggest that the deterioration of air quality near the surface in hazy days in the analyzed period is mainly caused by the increase of fine mode aerosol due to particle hygroscopic growth triggered by high RH. Moreover, the analyzed satellite observations demonstrate the evident impact of meteorological changes on the variation in aerosol components during air pollution. However, satellite observations were missing on the 19th and 20th due to cloudy conditions and a two-day revisit period of the satellite. Indeed, satellites can get continuous data for a large area, but the revisit time of the satellites is limited (e.g., it is once in 2 days for PARASOL). In addition, the presence of clouds greatly reduces the availability of effective data. In this study, cloudy pixel percentage is about $30 \%$ over NCP in January 2012. At the same time, in other studies, the cloud is also an important influence on the amount of effective data.

Figure 13 presents comparisons of fine mode aerosol component mass concentrations retrieved from satellite and from surface measurements of $\mathrm{PM}_{2.5}$ over Beijing in January 2012. The values of aerosol component values retrieved for fine mode (BC, BrC FNAS and FNAI) represent the mass concentration in the entire atmosphere, while the $\mathrm{PM}_{2.5}$ measured represents the surface level. Nonetheless, the concentrations of fine mode aerosol components and the $\mathrm{PM}_{2.5}$ demonstrate a consistent variation trend, with the 
correlation coefficients $(\mathrm{R})$ of 0.84 except for one outlier. This suggests that fine-mode aerosol components have a significant and possibly dominant impact on $\mathrm{PM}_{2.5}$ [63].
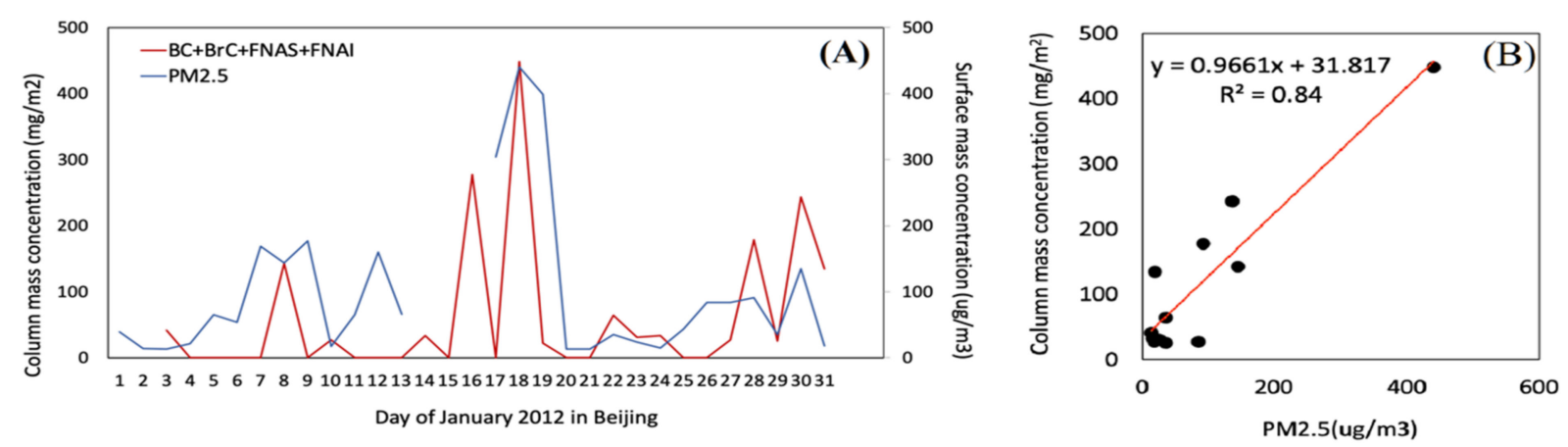

Figure 13. (A) Daily average of integral BC, BrC, FNAS, FNAI mass concentrations obtained from remote sensing retrieval compared with in situ $\mathrm{PM}_{2.5}$ measurements during January 2012 in Beijing. (B) Correlation of $\mathrm{PM}_{2.5}$ value with integral BC, BrC, FNAS, FNAI mass concentration during January 2012 in Beijing.

Thus, this study illustrated that the GRASP/Component approach can effectively distinguish various aerosol components. The retrieval results are especially promising for identifying strongly absorbing components. For example, the derived spatial distribution of $\mathrm{BC}$ and $\mathrm{BrC}$ reasonably agrees with physical expectations and is consistent with the results of previous research works. In addition, the study showed that the concentration of ASC over a few desert areas is higher than in a coastal area. However, due to the lack of ground-based and in situ measurements required for reliable validations of the result, the accuracy of the ASC component remains to be further investigated. Furthermore, climate assessments generally rely on the Global Climate Model (GCM) which provides aerosol component including organic matter. For the moment, this component is not retrieved separately by the GRASP/component approach or other satellite retrievals. Therefore, in the future for aligning satellite components characterization with GCM forecasts, it is desirable to derive the organic aerosol as a separate aerosol component in an inversion of satellite observations.

\section{Conclusions}

The GRASP/component retrieval was applied to POLDER-3/PARASOL satellite remote sensing observations for characterizing the distribution of aerosol components over the NCP region during January 2012. The retrieved AOD, AAOD, AOD $\mathrm{f}_{\mathrm{f}}$ and $\mathrm{k}_{\mathrm{f}}$, $\mathrm{k}_{\mathrm{c}}, \mathrm{n}_{\mathrm{f}}, \mathrm{n}_{\mathrm{c}}, \mathrm{FMFv}$ were analyzed in the study. The aerosol characteristics retrieved by GRASP/component were then regripped to a new set of the components for convenience and clarity of the intercomparison. The new set of aerosol components is comprised of six main components: black carbon $(\mathrm{BC})$, brown carbon $(\mathrm{BrC})$, dust-like (DU), fine ammonium sulfate (ASF), coarse ammonium sulfate (ASC) and aerosol water content (AW).

The derived spatial distributions of $\mathrm{AOD}$ and $\mathrm{AOD}_{\mathrm{f}}$ showed the domination of fine particles dominate during polluted haze events in Hebei. The regional distributions of $\mathrm{k}_{\mathrm{f}}$ $\mathrm{k}_{\mathrm{c}}, \mathrm{n}_{\mathrm{f}}$ and $\mathrm{n}_{\mathrm{c}}$, were related to a variation of the water content and absorbing ability of aerosol particles, respectively. In addition, the retrieval results exhibited clear spectrally decreasing tendency for aerosol optical properties such as AOD, AAOD and $\mathrm{AOD}_{\mathrm{f}}$. The results of aerosol component retrieval showed a pronounced BC burden in Shanxi, reaching $2 \%$. The highest values of $\mathrm{BrC}$ fraction of up to $7 \%$ occurred in Hebei. ASF were mainly detected in the Bohai Bay area. The significant presence of dust aerosol was observed mainly over the North China Plain during the winter season. The conducted validation of AOD, AAOD, $\mathrm{AOD}_{\mathrm{f}}$ had fairly good agreement with ground-based measurements. The comparison of $\mathrm{k}_{\mathrm{f}}, \mathrm{k}_{\mathrm{c}}, \mathrm{n}_{\mathrm{f}}, \mathrm{n}_{\mathrm{c}}$ values showed convincing agreement with conclusions by Zhang et al. [17]. Similarly, the following results of obtained aerosol component distribution are generally consistent with the conclusion drawn by previous research. For example, analysis of the 
spatial distributions of aerosol components suggested that the BC is mainly present in northwestern Shanxi. In these regards, it is noteworthy to mention that the Shanxi province disposes a rich storage of coal resources in China. The elevated concentrations of $\mathrm{BrC}$ are mainly detected over Beijing, Tianjin, southern Hebei and northern Shandong. The high values of $\mathrm{BrC}$ mass concentration (up to $127 \mathrm{mg} / \mathrm{m}^{2}$ ) can be an indication of the specificity of the primary air pollution sources in these areas.

The relationships between air quality, meteorological data and derived aerosol components were analyzed by comparing the situations during the non-haze (on 3 January 2012) and haze (on 17 January 2012) cases in the BJ region (see Figure 1). The observations showed that the mass concentrations of $\mathrm{BrC}$ can be two times and of ASF four times larger on a haze than non-haze day accordingly. The high values of $\mathrm{BrC}$ and $\mathrm{ASF}$ concentration corresponded to daily $\mathrm{PM}_{2.5}$ concentration values reaching up to $425 \mathrm{~g} / \mathrm{m}^{3}$ and $\mathrm{RH}$ values reaching up to $80 \%$. These values likely can be attributed to the high presence of anthropogenic pollution. Finally, the obtained results suggested that the stagnant meteorological conditions are favorable to the generation and accumulation of secondary aerosol components. The reported results are expected to be of high value for the research of climatic and atmospheric environment tendencies and patterns.

Author Contributions: Y.O. performed the inversion and prepared the paper. Z.L. conceived on the paper. Y.Z. designed the study and modification. O.D. developed the GRASP algorithm and revised the logic and expression of the paper. Y.D. gave the corrections and comments of the paper. L.L. improved the GRASP/components algorithm and gave some comments. C.C. provided the parameter information of GRASP software and provided advice on validation. D.F. provided the GRASP software. Y.X. gave advice on the design of the figures. A.L. and F.D. provided the suggestions on configuring MPI of GRASP software. Z.P. revised the language of the article. All authors have read and agreed to the published version of the manuscript.

Funding: This work was supported by the National Outstanding Youth Foundation of China (Grant No. 41925019). This work was also supported by the National Key B\&R Program of China (Grant No. 2016YFE0201400). This work was also supported by the Hainan Provincial Natural Science Foundation of China (Grant NO. 418QN302). The GRASP/components algorithm was supported by the CaPPA project (Chemical and Physical Properties of the Atmosphere), funded by the French National Research Agency through the Programmed'Investissement d'Avenir under contract "ANR11- LABX-0005-01" and by the Regional Council Nord Pas de Calais-Picardie and the European Funds for Regional Economic Development.

Institutional Review Board Statement: Not applicable.

Informed Consent Statement: Informed consent was obtained from all subjects involved in the study.

Data Availability Statement: The data presented in this study are available on request from the corresponding author.

Acknowledgments: Thanks to the entire GRASP-OPEN (https: / www.grasp-open.com/, (accessed on 4 July 2021)) team for the algorithm development. We would also like to express our thankfulness to CNES and ICARE data distribution center for POLDER/PARASOL data. We are grateful to Beijing, Xianghe, Xinglong AERONET sites for ground-based data and to the US Embassy of Beijing for providing $\mathrm{PM}_{2.5}$ observation data (https: / / china.usembassy-china.org.cn/, (accessed on 4 July 2021)) and meteorological stations of China Meteorological Administration (CMA).

Conflicts of Interest: The authors declare no conflict of interest. The funders had no role in the design of the study; in the collection, analyses, or interpretation of data; in the writing of the manuscript, or in the decision to publish the results.

\section{References}

1. Richter, A.; Burrows, J.P.; Nüß, H.; Granier, C.; Niemeier, U. Increase in tropospheric nitrogen dioxide over China observed from space. Nature 2005, 437, 129-132. [CrossRef] [PubMed]

2. Huang, R.J.; Zhang, Y.; Bozzetti, C.; Ho, K.F.; Cao, J.J.; Han, Y.; Daellenbach, K.R.; Slowik, J.G.; Platt, S.M.; Canonaco, F.; et al. High secondary aerosol contribution to particulate pollution during haze events in China. Nature 2014, 514, 218-222. [CrossRef] [PubMed] 
3. Li, W.J.; Shao, L.Y.; Buseck, P.R. Haze types in Beijing and the influence of agricultural biomass burning. Atmos. Chem. Phys. 2010, 10, 8119-8130. [CrossRef]

4. Wang, Y.; Zhuang, G.; Sun, Y.; An, Z. The variation of characteristics and formation mechanisms of aerosols in dust, haze, and clear days in Beijing. Atmos. Environ. 2006, 40, 6579-6591. [CrossRef]

5. Tang, L.; Zhang, Y.; Sun, Y.; Yu, H.; Jiang, R. Components and optical properties of submicron aerosol during the lasting haze period in Nanjing. Chin. Sci. Bull. 2014, 59, 1955.

6. Han, T.; Liu, X.; Zhang, Y.; Qu, Y.; Zeng, L.; Hu, M.; Zhu, T. Role of secondary aerosols in haze formation in summer in the Megacity Beijing. J. Environ. Sci. Engl. 2015, 31, 51-60. [CrossRef]

7. Sun, C.; Zhao, W.; Zhang, Q.; Yu, X.; Zheng, X.; Zhao, J.; Lv, M. Spatial Distribution, Sources Apportionment and Health Risk of Metals in Topsoil in Beijing, China. Int. J. Environ. Res. Public Health 2016, 13, 727. [CrossRef]

8. Cao, J.J.; Wu, F.; Chow, J.C.; Lee, S.C.; Li, Y.; Chen, S.W.; An, Z.S.; Fung, K.K.; Watson, J.G.; Zhu, C.S. Characterization and source apportionment of atmospheric organic and elemental carbon during fall and winter of 2003 in Xi'an, China. Atmos. Chem. Phys. 2005, 5, 3127-3137. [CrossRef]

9. Cao, J.; Lee, S.; Ho, K.F.; Zhang, X.; Zou, S.; Fung, K.; Chow, J.; Watson, J. Characteristics of carbonaceous aerosol in Pearl River Delta Region, China during 2001 winter period. Atmos. Environ. 2003, 37, 1451-1460. [CrossRef]

10. Arola, A.; Schuster, G.; Myhre, G.; Kazadzis, S.; Dey, S.; Tripathi, S.N. Inferring absorbing organic carbon content from AERONET data. Atmos. Chem. Phys. Discuss. 2010, 10, 215-225.

11. Li, Z.; Gu, X.; Wang, L.; Li, D.; Xie, Y.; Li, K.; Dubovik, O.; Schuster, G.; Goloub, P.; Zhang, Y.; et al. Aerosol physical and chemical properties retrieved from ground-based remote sensing measurements during heavy haze days in Beijing winter. Atmos. Chem. Phys. 2013, 13, 10171-10183. [CrossRef]

12. Li, Z.; Li, L.; Zhang, F.; Li, D.; Xie, Y.; Xu, H. Comparison of aerosol properties over Beijing and Kanpur: Optical, physical properties and aerosol component composition retrieved from 12 years ground-based Sun-sky radiometer remote sensing data. J. Geophys. Res. Atmos. 2015, 120, 1520-1535. [CrossRef]

13. Schuster, G.L. Inferring black carbon content and specific absorption from Aerosol Robotic Network (AERONET) aerosol retrievals. J. Geophys. Res. 2005, 110. [CrossRef]

14. Schuster, G.L.; Bing, L.; Dubovik, O. Remote sensing of aerosol water uptake. Geophys. Res. Lett. 2009, 36. [CrossRef]

15. Schuster, G.L.; Dubovik, O.; Arola, A. Remote sensing of soot carbon-Part 1: Distinguishing different absorbing aerosol species. Atmos. Chem. Phys. 2016, 16, 1565-1585. [CrossRef]

16. Zhang, Y.; Li, Z.; Sun, Y.; Lv, Y.; Xie, Y. Estimation of atmospheric columnar organic matter (OM) mass concentration from remote sensing measurements of aerosol spectral refractive. Atmos. Environ. 2018, 179, 107-117. [CrossRef]

17. Zhang, Y.; Li, Z.; Chen, Y.; de Leeuw, G.; Zhang, C.; Xie, Y.; Li, K. Improved inversion of aerosol components in the atmospheric column from remote sensing data. Atmos. Chem. Phys. 2020, 20, 12795-12811. [CrossRef]

18. Li, L.; Dubovik, O.; Derimian, Y.; Schuster, G.L.; Lapyonok, T.; Litvinov, P.; Ducos, F.; Fuertes, D.; Chen, C.; Li, Z.; et al. Retrieval of aerosol components directly from satellite and ground-based measurements. Atmos. Chem. Phys. 2019, 19, 13409-13443. [CrossRef]

19. Dubovik, O.; Li, Z.; Mishchenko, M.I.; Tanré, D.; Karol, Y.; Bojkov, B.; Cairns, B.; Diner, D.J.; Espinosa, W.R.; Goloub, P.; et al. Polarimetric remote sensing of atmospheric aerosols: Instruments, methodologies, results, and perspectives. J. Quant. Spectrosc. Radiat. Transf. 2019, 224, 474-511. [CrossRef]

20. Hasekamp, O.P.; Litvinov, P.; Butz, A. Aerosol properties over the ocean from PARASOL multiangle photopolarimetric measurements. J. Geophys. Res. 2011. [CrossRef]

21. Dubovik, O.; Herman, M.; Holdak, A.; Lapyonok, T.; Tanré, D.; Deuzé, J.L.; Ducos, F.; Sinyuk, A.; Lopatin, A. Statistically optimized inversion algorithm for enhanced retrieval of aerosol properties from spectral multi-angle polarimetric satellite observations. Atmos. Meas. Tech. 2011, 4, 975-1018. [CrossRef]

22. Russell, P.B.; Hamill, P.; Livingston, J.M.; Shinozuka, Y.; Strawa, A.W.; Redemann, J.; Omar, A.H.; Clarke, A.D.; Bergstrom, R.W.; Holben, B. Identifying Aerosol Type from Space: Absorption Angstrom Exponent as a Foundation for Multidimensional Supervised Clustering and Mahalanobis Classification. In AGU Fall Meeting Abstracts; NASA: Washington, DC, USA, 2010.

23. Chen, C.; Dubovik, O.; Henze, D.K.; Lapyonak, T.; Chin, M.; Ducos, F.; Litvinov, P.; Huang, X.; Li, L. Retrieval of desert dust and carbonaceous aerosol emissions over Africa from POLDER/PARASOL products generated by the GRASP algorithm. Atmos. Chem. Phys. 2018, 18, 12551-12580. [CrossRef]

24. Chen, C.; Dubovik, O.; Henze, D.K.; Chin, M.; Lapyonok, T.; Schuster, G.L.; Ducos, F.; Fuertes, D.; Litvinov, P.; Li, L.; et al. Constraining global aerosol emissions using POLDER/PARASOL satellite remote sensing observations. Atmos. Chem. Phys. 2019, 19, 14585-14606. [CrossRef]

25. Dubovik, O.; Lapyonok, T.; Litvinov, P.; Herman, M.; Federspiel, C. GRASP: A versatile algorithm for characterizing the atmosphere. Spienewsroom 2014, 25, 2-1201408. [CrossRef]

26. Li, L.; Che, H.; Derimian, Y.; Dubovik, O.; Luan, Q.; Li, Q.; Huang, X.; Zhao, H.; Gui, K.; Zheng, Y. Climatology of Fine and Coarse Mode Aerosol Optical Thickness Over East and South Asia Derived From POLDER/PARASOL Satellite. J. Geophys. Res. Atmos. 2020, 125, e2020JD032665. [CrossRef]

27. Li, L.; Che, H.; Derimian, Y.; Dubovik, O.; Zhang, X. Retrievals of fine mode light-absorbing carbonaceous aerosols from POLDER/PARASOL observations over East and South Asia. Remote Sens. Environ. 2020, 247, 111913. [CrossRef] 
28. Deschamps, P.Y.; Breon, F.M.; Leroy, M.; Podaire, A.; Bricaud, A.; Buriez, J.C.; Seze, G. The POLDER mission: Instrument characteristics and scientific objectives. IEEE Trans. Geosci. Remote Sens. 1994, 32, 598-615. [CrossRef]

29. Deuzé, J.L.; Bréon, F.M.; Devaux, C.; Goloub, P.; Herman, M.; Lafrance, B.; Maignan, F.; Marchand, A.; Nadal, F.; Perry, G.; et al. Remote sensing of aerosols over land surfaces from POLDER-ADEOS-1 polarized measurements. J. Geophys. Res. Atmos. 2001, 106, 4913-4926. [CrossRef]

30. Deuzé, J.L.; Goloub, P.; Herman, M.; Marchand, A.; Perry, G.; Susana, S.; Tanré, D. Estimate of the aerosol properties over the ocean with POLDER. J. Geophys. Res. Atmos. 2000, 105, 15329-15346. [CrossRef]

31. Tanré, D.; Bréon, F.M.; Deuzé, J.L.; Dubovik, O.; Ducos, F.; François, P.; Goloub, P.; Herman, M.; Lifermann, A.; Waquet, F. Remote sensing of aerosols by using polarized, directional and spectral measurements within the A-Train: The PARASOL mission. Atmos. Meas. Tech. 2011, 4, 1383-1395. [CrossRef]

32. Chen, C.; Dubovik, O.; Fuertes, D.; Litvinov, P.; Lapyonok, T.; Lopatin, A.; Ducos, F.; Derimian, Y.; Herman, M.; Tanré, D.; et al. Validation of GRASP algorithm product from POLDER/PARASOL data and assessment of multi-angular polarimetry potential for aerosol monitoring. Earth Syst. Sci. Data 2020, 12, 3573-3620. [CrossRef]

33. Schutgens, N.; Dubovik, O.; Hasekamp, O.; Torres, O.; Jethva, H.; Leonard, P.J.T.; Litvinov, P.; Redemann, J.; Shinozuka, Y.; de Leeuw, G.; et al. AEROCOM and AEROSAT AAOD and SSA study_Part 1: Evaluation and intercomparison of satellite measurements. Atmos. Chem. Phys. 2021, 21, 6895-6917. [CrossRef]

34. Holben, B.N.; Eck, T.F.; Slutsker, I.; Tanré, D.; Buis, J.P.; Setzer, A.; Vermote, E.; Reagan, J.A.; Kaufman, Y.J.; Nakajima, T. AERONET-A Federated Instrument Network and Data Archive for Aerosol Characterization. Remote Sens. Environ. 1998, 66, 1-16. [CrossRef]

35. Lee, J.; Kim, J.; Song, C.H.; Kim, S.B.; Chun, Y.; Sohn, B.J.; Holben, B.N. Characteristics of aerosol types from AERONET sunphotometer measurements. Atmos. Environ. 2010, 44, 3110-3117. [CrossRef]

36. Giles, D.M.; Holben, B.N.; Eck, T.F.; Sinyuk, A.; Smirnov, A.; Slutsker, I.; Dickerson, R.; Thompson, A.; Schafer, J. An analysis of AERONET aerosol absorption properties and classifications representative of aerosol source regions. J. Geophys. Res. Atmos. 2012, 117. [CrossRef]

37. Eck, T.F.; Holben, B.N.; Reid, J.S.; Dubovik, O.; Smirnov, A.; O’Neill, N.T.; Slutsker, I.; Kinne, S. Wavelength dependence of the optical depth of biomass burning, urban, and desert dust aerosols. J. Geophys. Res. Atmos. 1999, 104, 31333-31349. [CrossRef]

38. Yang, H.A.; Vokla, B.; Jckla, B.; Mp, B. How BLUE is the Sky? Estimating air qualities in Beijing during the Blue Sky Day period (2008-2012) by Bayesian Multi-task LSTM-ScienceDirect. Environ. Sci. Policy 2021, 116, 69-77.

39. Guo, J.; Niu, T.; Wang, F.; Deng, M.; Wang, Y. Integration of multi-source measurements to monitor sand-dust storms over North China: A case study. Acta Meteorol. Sin. 2013, 27, 566-576. [CrossRef]

40. Hu, X.M.; Ma, Z.Q.; Lin, W.; Zhang, H.; Hu, J.; Wang, Y.; Xu, X.; Fuentes, J.D.; Xue, M. Impact of the Loess Plateau on the atmospheric boundary layer structure and air quality in the North China Plain: A case study. Sci. Total Environ. 2014, 499, 228-237. [CrossRef]

41. Sun, Y.; Wang, Z.; Fu, P.; Jiang, Q.; Yang, T.; Li, J.; Ge, X. The impact of relative humidity on aerosol composition and evolution processes during wintertime in Beijing, China. Atmos. Environ. 2013, 77, 927-934. [CrossRef]

42. Wang, L.; Xin, J.; Li, X.; Wang, Y. The variability of biomass burning and its influence on regional aerosol properties during the wheat harvest season in North China. Atmos. Res. 2015, 157, 153-163. [CrossRef]

43. Xia, X.A.; Chen, H.B.; Wang, P.C.; Zong, X.M.; Qiu, J.H.; Gouloub, P. Aerosol properties and their spatial and temporal variations over North China in spring 2001. Tellus Ser. B Chem. Phys. Meteorol. 2005, 57, 28-39.

44. Zhao, X.J.; Zhao, P.S.; Xu, J.; Meng, W.; Pu, W.W.; Dong, F.; He, D.; Shi, Q.F. Analysis of a winter regional haze event and its formation mechanism in the North China Plain. Atmos. Chem. Phys. 2013, 13, 5685-5696. [CrossRef]

45. Zhang, H.; Wang, Z.; Zhang, W. Exploring spatiotemporal patterns of PM2.5 in China based on ground-level observations for 190 cities. Environ. Pollut. 2016, 216, 559-567. [CrossRef]

46. Li, J.; Wang, G.; Ren, Y.; Wang, J.; Wu, C.; Han, Y.; Zhang, L.; Cheng, C.; Meng, J. Identification of chemical compositions and sources of atmospheric aerosols in Xi'an, inland China during two types of haze events. Sci. Total Environ. 2016, 566-567, 230-237. [CrossRef]

47. Benavent-Oltra, J.A.; Román, R.; Granados-Muñoz, M.J.; Pérez-Ramírez, D.; Ortiz-Amezcua, P.; Denjean, C.; Lopatin, A.; Lyamani, H.; Torres, B.; Guerrero-Rascado, J.L.; et al. Comparative assessment of GRASP algorithm for a dust event over Granada (Spain) during ChArMEx-ADRIMED 2013 campaign. Atmos. Meas. Tech. 2017, 10, 4439-4457. [CrossRef]

48. Román, R.; Torres, B.; Fuertes, D.; Cachorro, V.E.; Dubovik, O.; Toledano, C.; Cazorla, A.; Barreto, A.; Bosch, J.L.; Lapyonok, T. Remote sensing of lunar aureole with a sky camera: Adding information in the nocturnal retrieval of aerosol properties with GRASP code. Remote Sens. Environ. 2017, 196, 238-252. [CrossRef]

49. Lopatin, A.; Dubovik, O.; Fuertes, D.; Stenchikov, G.; Parajuli, S. Synergy processing of diverse ground-based remote sensing and in situ data using GRASP algorithm: Applications to radiometer, lidar and radiosonde observations. Atmos. Meas. Tech. 2020, 14, 2575-2614. [CrossRef]

50. Espinosa, W.R.; Remer, L.A.; Dubovik, O.; Ziemba, L.; Beyersdorf, A.; Orozco, D.; Schuster, G.; Lapyonok, T.; Fuertes, D.; Martins, J.V. Retrievals of aerosol optical and microphysical properties from Imaging Polar Nephelometer scattering measurements. Atmos. Meas. Tech. 2017, 10, 811-824. [CrossRef] 
51. Dubovik, O.; Sinyuk, A.; Lapyonok, T.; Holben, B.N.; Mishchenko, M.; Yang, P.; Eck, T.F.; Volten, H.; Muñoz, O.; Veihelmann, B.; et al. Application of spheroid models to account for aerosol particle nonsphericity in remote sensing of desert dust. J. Geophys. Res. Atmos. 2006, 111. [CrossRef]

52. Lenoble, J.; Herman, M.; Deuzé, J.L.; Lafrance, B.; Santer, R.; Tanré, D. A successive order of scattering code for solving the vector equation of transfer in the earth's atmosphere with aerosols. J. Quant. Spectrosc. Radiat. Transf. 2007, 107, 479-507. [CrossRef]

53. Dubovik, O. Optimization of Numerical Inversion in Photopolarimetric Remote Sensing. In Photopolarimetry in Remote Sensing; Springer: Dordrecht, The Netherlands, 2004.

54. Choi, Y.; Ghim, Y.S. Estimation of columnar concentrations of absorbing and scattering fine mode aerosol components using AERONET data. J. Geophys. Res. Atmos. 2016, 121, 13628-13640. [CrossRef]

55. Bohren, C.F.; Huffman, D.R. Absorption and Scattering of Light by Small Particles; John Wiley \& Sons: Hoboken, NJ, USA, 2008.

56. Wang, L.; Li, Z.; Tian, Q.; Ma, Y.; Zhang, F.; Zhang, Y.; Li, D.; Li, K.; Li, L. Estimate of aerosol absorbing components of black carbon, brown carbon, and dust from ground-based remote sensing data of sun-sky radiometers. J. Geophys. Res. Atmos. 2013, 118, 6534-6543. [CrossRef]

57. Dubovik, O.; Holben, B.; Eck, T.F.; Smirnov, A.; Kaufman, Y.J.; King, M.D.; Tanré, D.; Slutsker, I. Variability of Absorption and Optical Properties of Key Aerosol Types Observed in Worldwide Locations. J. Atmos. Sci. 2002, 59, 590-608. [CrossRef]

58. Davies, C.N. Size distribution of atmospheric particles. J. Aerosol. Sci. 1974, 5, 293-300. [CrossRef]

59. Raabe, O.G. Particle size analysis utilizing grouped data and the log-normal distribution. J. Aerosol. Sci. 1971, 2, 289-303. [CrossRef]

60. Whitey, K.T. The physical characteristics of sulfur aerosols. Atmos. Environ. 1978, 12, 135-159. [CrossRef]

61. Aitchison, J.; Brown, J.A.C. The lognormal distribution with special reference to its uses in economics. J. Polit. Econ. 1957, 25, 142-143.

62. Hou, W.; Li, Z.; Wang, J.; Xu, X.; Goloub, P.; Qie, L. Improving Remote Sensing of Aerosol Microphysical Properties by NearInfrared Polarimetric Measurements Over Vegetated Land: Information Content Analysis. J. Geophys. Res. Atmos. 2018, 123, 2215-2243. [CrossRef]

63. Zhang, X.Y.; Wang, Y.Q.; Niu, T.; Zhang, X.C.; Gong, S.L.; Zhang, Y.M.; Sun, J.Y. Atmospheric aerosol compositions in China: Spatial/temporal variability, chemical signature, regional haze distribution and comparisons with global aerosols. Atmos. Chem. Phys. 2012, 12, 779-799. [CrossRef]

64. Zhang, X.Y.; Wang, Y.Q.; Zhang, X.C.; Guo, W.; Gong, S.L. Carbonaceous aerosol composition over various regions of China during 2006. J. Geophys. Res. Atmos. 2008, 113. [CrossRef]

65. Ge, B.; Mei, X.; Li, Z.; Hou, W.; Xie, Y.; Zhang, Y.; Xu, H.; Li, K.; Wei, Y. An improved algorithm for retrieving high resolution fine-mode aerosol based on polarized satellite data: Application and validation for POLDER-3. Remote Sens. Environ. $2020,247$. [CrossRef]

66. Wei, Y.; Li, Z.; Zhang, Y.; Chen, C.; Dubovik, O.; Zhang, Y.; Xu, H.; Li, K.; Chen, J.; Wang, H.; et al. Validation of POLDER GRASP aerosol optical retrieval over China using SONET observations. J. Quant. Spectrosc. Radiat. Transf. 2020, 246. [CrossRef]

67. Streets, D.G.; Gupta, S.; Waldhoff, S.T.; Wang, M.Q.; Bond, T.C.; Bo, Y. Black carbon emissions in China. Atmos. Environ. 2002, 35, 4281-4296. [CrossRef]

68. Wang, S.; Crumeyrolle, S.; Zhao, W.; Xu, X.; Tong, Y. Real-time retrieval of aerosol chemical composition using effective density and the imaginary part of complex refractive index. Atmos. Environ. 2021, 245, 117959. [CrossRef]

69. Sun, H.; Biedermann, L.; Bond, T.C. Color of brown carbon: A model for ultraviolet and visible light absorption by organic carbon aerosol. Geophys. Res. Lett. 2007, 34. [CrossRef]

70. Koven, C.D.; Fung, I. Inferring dust composition from wavelength-dependent absorption in Aerosol Robotic Network (AERONET) data. J. Geophys. Res. Atmos. 2006, 111. [CrossRef]

71. Van Beelen, A.J.; Roelofs, G.J.H.; Hasekamp, O.P.; Henzing, J.S.; Röckmann, T. Estimation of aerosol water and chemical composition from AERONET Sun-sky radiometer measurements at Cabauw, the Netherlands. Atmos. Chem. Phys. 2014, 14, 5969-5987. [CrossRef]

72. Xie, Y.S.; Li, Z.Q.; Zhang, Y.X.; Zhang, Y.; Li, D.H.; Li, K.T.; Xu, H.; Zhang, Y.; Wang, Y.Q.; Chen, X.F.; et al. Estimation of atmospheric aerosol composition from ground-based remote sensing measurements of Sun-sky radiometer. J. Geophys. Res. Atmos. 2017, 122, 498-518. [CrossRef] 